\title{
Synthesis, Binding Affinity, and Molecular Docking Analysis of New Benzofuranone Derivatives as Potential Antipsychotics
}

\author{
Reyes Aranda ${ }^{\dagger}$ Karen Villalba $^{\dagger}$ Enrique Raviña, ${ }^{\dagger}$ Christian F. Masaguer, ${ }^{*}{ }^{\dagger}$ José Brea, ${ }^{\ddagger}$ Filipe Areias, ${ }^{\ddagger}$ Eduardo Domínguez, ${ }^{\ddagger}$ \\ Jana Selent, ${ }^{\S}$ Laura López, ${ }^{\S}$ Ferran Sanz, ${ }^{\S}$ Manuel Pastor, ${ }^{\S}$ and María I. Loza \\ Departamento de Química Orgánica, Laboratorio de Química Farmacéutica, and Departamento de Farmacología, Facultad de Farmacia, \\ Universidad de Santiago de Compostela, E-15782 Santiago de Compostela, Spain, and Research Unit on Biomedical Informatics (GRIB), \\ IMIM, Universitat Pompeu Fabra, Dr. Aiguader 88, E-08003 Barcelona, Spain
}

Received May 21, 2008

\begin{abstract}
The complex etiology of schizophrenia has prompted researchers to develop clozapine-related multitarget strategies to combat its symptoms. Here we describe a series of new 6-aminomethylbenzofuranones in an effort to find new chemical structures with balanced affinities for 5- $\mathrm{HT}_{2}$ and dopamine receptors. Through biological and computational studies of 5- $\mathrm{HT}_{2 \mathrm{~A}}$ and $\mathrm{D}_{2}$ receptors, we identified the receptor serine residues S3.36 and S5.46 as the molecular keys to explaining the differences in affinity and selectivity between these new compounds for this group of receptors. Specifically, the ability of these compounds to establish one or two H-bonds with these key residues appears to explain their difference in affinity. In addition, we describe compound 2 (QF1004B) as a tool to elucidate the role of 5- $\mathrm{HT}_{2 \mathrm{C}}$ receptors in mediating antipsychotic effects and metabolic adverse events. The compound 16a (QF1018B) showed moderate to high affinities for $\mathrm{D}_{2}$ and $5-\mathrm{HT}_{2 \mathrm{~A}}$ receptors, and a $5-\mathrm{HT}_{2 \mathrm{~A}} / \mathrm{D}_{2}$ ratio was predictive of an atypical antipsychotic profile.
\end{abstract}

\section{Introduction}

Schizophrenia is a severe disorder that affects around 24 million people worldwide, and it typically begins in late adolescence or early adulthood. It is characterized by profound disruptions in thinking, and it affects language, perception, and a sense of self. It often includes psychotic experiences such as hearing voices or delusions. It can impair functioning through the loss of the acquired capability of earning one's own livelihood or through the disruption of studies. ${ }^{1}$ Classical (typical) neuroleptics such as haloperidol (Figure 1) are currently used to treat this disease, but their use is associated with severe mechanism-related side effects including the induction of acute extrapyramidal symptoms (EPS) ${ }^{a}{ }^{2}$ Also, these compounds are ineffective against the negative symptoms of schizophrenia. A common feature of the clinical effects of classical antipsychotics is their ability to block dopamine $\mathrm{D}_{2}$ receptors in the brain. ${ }^{3-5}$ However, it has been reported that the blockage of the dopamine receptor in the striatum is closely associated with EPS. ${ }^{6,7}$

Four decades after its introduction into the clinic, clozapine remains the prototype for atypical antipsychotic drugs. Its reintroduction for use in cases of treatment-resistant schizophrenia gave rise to a new group of atypical or nonclassical antipsychotics that have no EPS at therapeutic doses and are also effective against schizophrenia's negative symptoms. ${ }^{8-10}$ These drugs exhibit potent antagonism at multiple receptor subtypes including serotonin and dopamine receptors, which suggests the involvement of the serotoninergic system in this

* To whom correspondence should be addressed. Tel: +34 981563100 Fax: +34 981594 912. E-mail: qojcfm@usc.es.

† Departamento de Química Orgánica, Universidad de Santiago de Compostela.

¥ Departamento de Farmacología. Universidad de Santiago de Compostela.

${ }^{\S}$ Universitat Pompeu Fabra.

a Abbreviations: EPS, extrapyramidal symptoms; 3D-QSAR, threedimensional quantitative structure-activity relationship; PF, Pseudomonas fluorescens; THF, tetrahydrofuran; TFAA, trifluoroacetic anhydride; TFA, trifluoroacetic acid; DCC, dicyclohexylcarbodiimide; HOBt, 1-hydroxybenzotriazole; FB, 4-fluorobenzoyl; BI, 6-fluorobenzisoxazolyl; SAR, structure-activity relationship; GPCR, G protein-coupled receptor. pathology. ${ }^{11,12}$ Since the $1980 \mathrm{~s},{ }^{13-15}$ a drug's relative affinity for the $\mathrm{D}_{2}$ and $5-\mathrm{HT}_{2 \mathrm{~A}}$ receptors has been used as a good predictive marker of an atypical antipsychotic profile, as is the case with clozapine, risperidone, and olanzapine. In fact, the ratio of a compound's $\mathrm{p} K_{\mathrm{i}}$ for $5-\mathrm{HT}_{2 \mathrm{~A}}$ and for $\mathrm{D}_{2}$, known as the Meltzer ratio, is used to discriminate atypical antipsychotics (ratio $>1.12$ ) from classical antipsychotics $(<1.09) .{ }^{16}$

Experimental and clinical studies seem to confirm the major role of the $5-\mathrm{HT}_{2 \mathrm{~A}}$ receptor in the atypical profile of antipsychotics. ${ }^{17-19}$ Additionally, many of the atypical antipsychotic agents block not only $5-\mathrm{HT}_{2 \mathrm{~A}}$ but also other serotonin receptors, and the set of affinities for the $5-\mathrm{HT}_{2 \mathrm{~A}}, 5-\mathrm{HT}_{2 \mathrm{C}}, 5-\mathrm{HT}_{6}, \mathrm{D}_{2}$, and $\mathrm{D}_{3}$ receptors is considered to be predictive of an optimal antipsychotic profile. ${ }^{20}$ Although there is no consensus on the involvement of the $5-\mathrm{HT}_{2 \mathrm{C}}$ receptor in the therapeutic profile ${ }^{21}$ or in the adverse metabolical events, ${ }^{11}$ this receptor remains a potential target in the treatment of psychotic illnesses. ${ }^{22,23}$

Despite clozapine's efficacy, it is associated with an increased risk of agranulocytosis, ${ }^{24}$ which strongly limits its therapeutic use. However, none of the other currently available drugs appear to have clozapine's spectrum of efficacy. Therefore, the discovery of novel antipsychotic agents that are chemically different, more effective, and free of side effects remains a challenging research goal.

As a part of our ongoing work in developing multitarget ligands for the potential use as treatments for schizophrenia, we have studied the modulation of the butyrophenone system with the aim of synthesizing a single molecule that can antagonize receptors of both the 5- $\mathrm{HT}_{2}$ and the $\mathrm{D}_{2}$ families. ${ }^{25-27}$ So far, we have reported the synthesis, pharmacology, and 3DQSAR analysis of a number of aminoalkyl-1-benzofuranones as potential antipsychotics. ${ }^{28}$ This study introduced the aminobutyrophenones 1-4 (substructure in bold), which show different pharmacological profiles (Table 1), and 6-aminomethylbenzofuranones $\mathbf{1}$ and $\mathbf{2}$, which exhibit a classical antipsychotic profile, whereas 5-aminoethylbenzofuranones $\mathbf{3}$ and $\mathbf{4}$ may display an atypical antipsychotic profile. 
<smiles>O=C(CCCN1CCC(O)(c2ccc(Cl)cc2)CC1)c1ccc(F)cc1</smiles>

Haloperidol

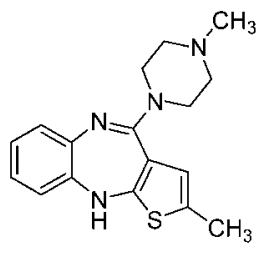

Olanzapine

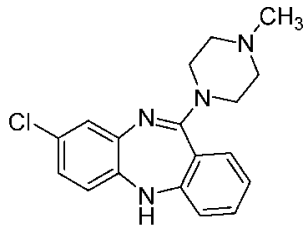

Clozapine

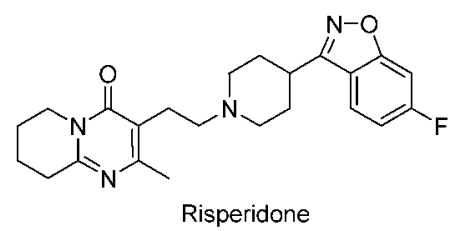

Risperidone
Figure 1. Structures of a typical (haloperidol) and some atypical antipsychotics.

Compounds 2 (QF1004B) and 4 (QF0703B) are closely structurally related and have affinities for the $5-\mathrm{HT}_{2 \mathrm{~A}}$ and $\mathrm{D}_{2}$ receptors, but their Meltzer ratios vary from 1.24 in the case of compound 4, which is characteristic of an atypical antipsychotic, to 1.06 in the case of $\mathbf{2}$, which is characteristic of a typical antipsychotic. These two compounds have been characterized as interesting pharmacological tools for the study of how a compound's antipsychotic profile is influenced by different selectivities for the 5- $\mathrm{HT}_{2}$ receptor subtypes (the potency of compound 4 at the 5- $\mathrm{HT}_{2 \mathrm{C}}$ receptor is approximately 10 times (1 log unit) higher than that of compound 2), by different $5-\mathrm{HT}_{2 \mathrm{~A}} / \mathrm{D}_{2}$ ratios (Meltzer ratios), and by different conformationdependent functional behaviors at the $5-\mathrm{HT}_{2 \mathrm{~A}}$ and $5-\mathrm{HT}_{2 \mathrm{C}}$ receptors. $^{29}$

To explore the therapeutic potential of the aminoalkylbenzofuranone cores of $\mathbf{1 - 4}$ further, we describe in this article the synthesis and binding affinity of a novel series of $5-\mathrm{HT}_{2} / \mathrm{D}_{2}$ ligands. To investigate the mode of receptor binding of these new compounds and to gain an understanding of the structural and conformational features that underlie their pharmacological properties, we docked some compounds into homology models of the dopamine $\mathrm{D}_{2}$ and serotonin $5-\mathrm{HT}_{2 \mathrm{~A}}$ receptors. The detailed analysis of the obtained complexes provides an excellent explanation of some of the largest differences in their binding affinities and thus validates the potential use of such complexes in the design of novel compounds.

Chemistry. The synthesis of the optically pure aminobutyrophenones (+)- and (-)-1 and (+)- and (-)-2 was accomplished by a lipase-catalyzed kinetic resolution of the intermediate 6-hydroxymethyl-4,5,6,7-tetrahydrobenzofuran-4one $(( \pm)-5)^{30}$ that used lipase from Pseudomonas fluorescens (PF) that was adsorbed on Celite in benzene (Scheme 1). This yielded the hydroxyketone $(-)-5(98 \%$ ee) and the acetate $(+)-6$ $(97 \%$ ee). Subsequent ester hydrolysis of $(+)-6$ with $\mathrm{LiOH}$ produced the corresponding hydroxymethylbenzofuranone $(+)-5$ in $78 \%$ yield. The bromination of the enantiomerically pure alcohols (Scheme 2), followed by the nucleophilic displacement of the bromine atom with 4-( $p$-fluorobenzoyl)piperidine, afforded (-)-1 and (+)-1, whereas the analogous reaction with 4-(6-fluorobenzisoxazol-3-yl)piperidine gave (-)-2 and (+)-2. The hydrochloride salts of these compounds prove to be suitable for use in binding assays.

The exact stereochemistry of these enantiomers could not be determined by crystallographic analysis. The absolute configuration was therefore assigned on the basis of the known configuration of the optically pure precursor $(S)$-4-(tert-butoxy)2-(furan-2-ylmethyl)-4-oxobutanoic acid (8). ${ }^{31}$ The synthetic route from this precursor to the hydroxymethylbenzofuranone 5 is depicted in Scheme 3. The carboxylic acid $(S)-8$ was reduced to the alcohol $(S)-\mathbf{9}$ by the use of a borane dimethyl sulfide complex in THF at $0{ }^{\circ} \mathrm{C}$. Subsequent acid-catalyzed cyclization yielded the lactone $(S)$-10, which was treated with $\mathrm{HBr}$ in acetic acid. The resulting bromoacid was cyclized to produce the bromobenzofuranone $(+)-7$ with the $S$ absolute configuration.

New compounds that bear different substituents on the furane ring were prepared as illustrated in Schemes 3 and 4. Different strategies of furannulation (Scheme 4) were applied to our previously described synthon $\mathbf{1 2}$, which was generated in situ from bis-enolether 11 by acid hydrolysis ${ }^{32}$ to obtain benzofuranone systems with different substituents.

Therefore, the condensation of diketone 12 with ethyl 2-bromopyruvate in methanolic $\mathrm{KOH}$ produced (6-hydroxymethyl-4-oxo-4,5,6,7-tetrahydrobenzofuran-3-yl)carboxylic acid (13a) as a yellow solid in $40 \%$ yield. This was esterified with diazomethane to yield 13d quantitatively.

The manganese(III) acetate-mediated addition ${ }^{33,34}$ of diketone $\mathbf{1 2}$ to phenylacetylene in glacial acetic acid afforded the desired phenylbenzofuranone 13b in $30 \%$ yield. Likewise, by following the method described by Stetter and Lauterbach, ${ }^{35}$ we cyclocondensed 12 with ethyl 2-chloroacetoacetate in the presence of $\mathrm{KOH}$ to produce the ester $\mathbf{1 3 c}$ in $40 \%$ yield.(Scheme 5).

The tosylation of alcohols $\mathbf{1 3 a}-\mathbf{c}$ with $p$-toluenesulfonyl chloride in anhydrous pyridine afforded the corresponding sulfonates $\mathbf{1 4 a}-\mathbf{c}$ in $50-65 \%$ yield (Scheme 4 ). The tosylates underwent nucleophilic substitution with 4-( $p$-fluorobenzoyl)piperidine or 4-(6-fluorobenzisoxazol-3-yl)piperidine to give the desired amines $\mathbf{1 5} \mathbf{a}-\mathbf{c}$ and $\mathbf{1 6} \mathbf{a}-\mathbf{c}$, respectively. Amide 18 was prepared in $45 \%$ yield from piperazine derivative $17^{30}$ by acidamine coupling with DCC carboxylate activation in the presence of HOBt (Scheme 6).

\section{Results and Discussion}

In some related compounds that were previously published by our group, we observed that the differences in the binding affinities of the $\mathrm{R}$ and $\mathrm{S}$ enantiomers are not large but they are certainly not negligible. ${ }^{36}$ Therefore, our first objective in the present study was to investigate whether the receptor affinities of these compounds correlate with the absolute stereochemistry. For this purpose, we prepared the benzofuranone derivative 2 as single enantiomers and determined their binding affinities for the $\mathrm{D}_{2}, 5-\mathrm{HT}_{2} \mathrm{~A}$, and $5-\mathrm{HT}_{2 \mathrm{C}}$ receptors. The affinities of the two enantiomers for cloned human $\mathrm{D}_{2}, 5-\mathrm{HT}_{2 \mathrm{~A}}$, and $5-\mathrm{HT}_{2 \mathrm{C}}$ receptors were evaluated by in vitro binding assays, and the data are summarized in Table 2 .

As shown in Table 2, the individual enantiomers and their racemic mixture show nearly identical affinities for the $5-\mathrm{HT}_{2 \mathrm{~A}}$, $5-\mathrm{HT}_{2} \mathrm{C}$, and $\mathrm{D}_{2}$ receptors. Consequently, it is not possible to correlate the absolute configuration with the potency in any of the receptors that were studied here.

The structures of the complexes that were obtained in the molecular modeling studies for the enantiomers of compound 2 fully support this finding. As expected, the piperidinylmethyl substituent always adopts an equatorial position, whereas the hydrogen that is attached to the chiral center adopts a pseudoaxial orientation in which it points toward different sides of the binding site depending on the configuration. These structural differences do not significantly affect the binding behavior, and as shown in Figure 2, both enantiomers can adopt nearly identical orientations within the receptor and thus establish the same polar interactions. 
Analysis of New Benzofuranone Derivatives

Journal of Medicinal Chemistry, 2008, Vol. 51, No. $19 \quad \mathbf{6 0 8 7}$

Table 1. Binding Profile of Compounds 1-4 for Dopamine $\mathrm{D}_{2}$ and Serotonins 5-HT $2 \mathrm{~A}$ and $5-\mathrm{HT}_{2 \mathrm{C}}$ Human Receptors ${ }^{a}$<smiles>O=C1CC(CN2CCC(C(=O)c3ccc(F)cc3)CC2)Cc2occc21</smiles><smiles>O=C1CC(CN2CCC(c3noc4cc(F)ccc34)CC2)Cc2occc21</smiles><smiles>O=C(c1ccc(F)cc1)C1CCN(CCC2CCc3occc3C2=O)CC1</smiles>

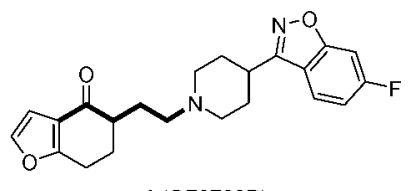

1 (QF1003B)

$2(\mathrm{QF} 1004 \mathrm{~B})$

$3(\mathrm{QF0702B)}$

4 (QF0703B)

\begin{tabular}{cccccc}
\hline compd & $\mathrm{p} K_{\mathrm{i}} \mathrm{D}_{2}$ & $\mathrm{p} K_{\mathrm{i}} 5-\mathrm{HT}_{2 \mathrm{~A}}$ & $\mathrm{p} K_{\mathrm{i}} 5-\mathrm{HT}_{2 \mathrm{C}}$ & $\mathrm{pA}_{2} 5-\mathrm{HT}_{2 \mathrm{~A}}$ & $\mathrm{MR}^{b}$ \\
\hline $\mathbf{1}(\mathrm{QF} 1003 \mathrm{~B})$ & $6.82 \pm 0.17$ & $7.02 \pm 0.14$ & $5.81 \pm 0.21$ & $7.28 \pm 0.07$ & 1.03 \\
$\mathbf{2}(\mathrm{QF1004B})$ & $7.79 \pm 0.18$ & $8.26 \pm 0.12$ & $6.47 \pm 0.26$ & $7.05 \pm 0.07$ & 1.06 \\
$\mathbf{3}$ (QF0702B) & $6.14 \pm 0.31$ & $7.11 \pm 0.20$ & $6.47 \pm 0.18$ & $7.58 \pm 0.20$ & 1.16 \\
$\mathbf{4}(\mathrm{QF} 0703 \mathrm{~B})$ & $7.34 \pm 0.13$ & $9.14 \pm 0.11$ & $7.46 \pm 0.30$ & $9.25 \pm 0.05$ & 1.24 \\
\hline
\end{tabular}

${ }^{a}$ Data are expressed as mean \pm SEM of three experiments. ${ }^{b} \mathrm{MR}=$ Meltzer ratio $\left(\mathrm{p} K_{\mathrm{i}} 5-\mathrm{HT}_{2 \mathrm{~A}} / \mathrm{p} K_{\mathrm{i}} \mathrm{D}_{2}\right)$.

Scheme $1^{a}$

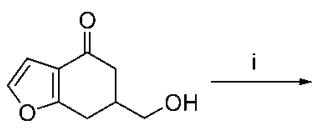

(士)-5<smiles>O=C1C[C@H](CO)Cc2occc21</smiles>

$(-)-5$

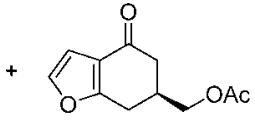

$(+)-6$

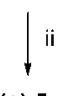

$(+)-5$

${ }^{a}$ Reagents and conditions: (i) vinyl acetate, lipase from PF, benzene, rt, $70 \mathrm{~h}$ and (ii) LiOH, DME, reflux, $17 \mathrm{~h}, 78 \%$.

Scheme $2^{a}$<smiles>O=C1CC(CO)Cc2occc21</smiles><smiles>CC(C)(C)c1cc2c(o1)CC(CBr)CC2=O</smiles><smiles>[R]NCC1CC(=O)c2ccoc2C1</smiles>

5

7

1,2

${ }^{a}$ Reagents and conditions: (i) $\mathrm{CBr}_{4}, \mathrm{PPh}_{3}, \mathrm{CH}_{2} \mathrm{Cl}_{2}$, reflux, 28 h, $95 \%$ and (ii) HNRR, NMP, $85^{\circ} \mathrm{C}, 16 \mathrm{~h}, 62-70 \%$.

Scheme $3^{a}$<smiles>CC(C)(C)OC(=O)CC(Cc1ccco1)C(=O)O</smiles>

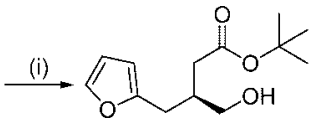

(S)-9

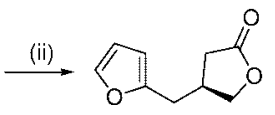

(S)-10

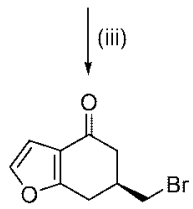

(S)-7

${ }^{a}$ Reagents and conditions: (i) $\left(\mathrm{CH}_{3}\right)_{2} \mathrm{~S} \cdot \mathrm{BH}_{3}$, THF, from $0{ }^{\circ} \mathrm{C}$ to rt, $2 \mathrm{~h}$, $86 \%$; (ii) $p$ - Ts OH, benzene, reflux, $3 \mathrm{~h}, 76 \%$; and (iii) (i) $\mathrm{HBr}, \mathrm{AcOH}, 80$ ${ }^{\circ} \mathrm{C}, 6 \mathrm{~h}$ and (ii) TFAA, TFA, rt, $12 \mathrm{~h}, 10 \%$ overall.

Because the stereochemistry of the chiral center does not seem to determine the affinities of these compounds for the target receptors, we focused our studies on the benzofuranone core. Therefore, several new compounds $(\mathbf{1 5 a}-\mathbf{c}$ and $\mathbf{1 6} \mathbf{a}-\mathbf{c})$ were prepared with substituent on the furan ring. The binding affinities of these new aminoalkylbenzofuranone derivatives at the dopamine $\mathrm{D}_{2}$ and serotonin $5-\mathrm{HT}_{2 \mathrm{~A}}$ and $5-\mathrm{HT}_{2 \mathrm{C}}$ receptors are summarized in Table 3.

Table 3 shows that the binding affinities of all of the derivatives that bear the $p$-fluorobenzoyl $(\mathrm{FB})$ moiety $(\mathbf{1 5 a}-\mathbf{c})$ are consistently lower than those of the compounds with the 6-fluorobenzisoxazolyl (BI) fragment $(\mathbf{1 6 a}-\mathbf{c})$. For the $5-\mathrm{HT}_{2 \mathrm{~A}}$ receptor, the difference in the affinities of the two series is of

Scheme $4^{a}$<smiles>COC1=CC(CO)C=C(OC)C1</smiles>

11

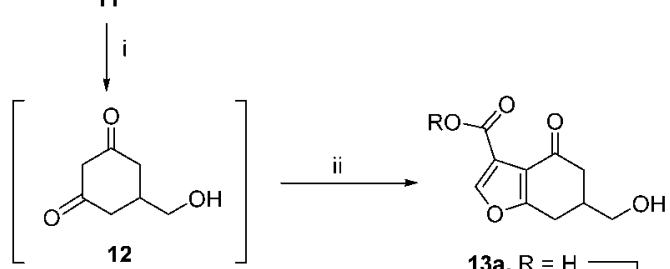

13a, $\mathrm{R}=\mathrm{H} \longrightarrow \mathrm{V}, \mathrm{R}=\mathrm{CH}_{3}$
13d
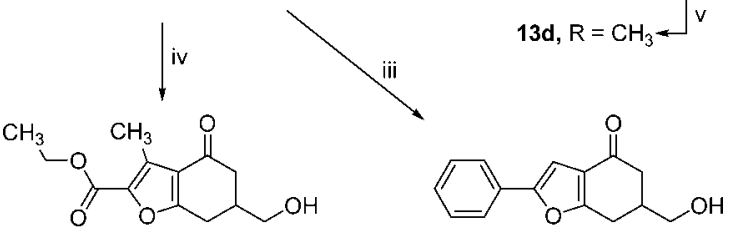

13b

${ }^{a}$ Reagents and conditions: (i) $\mathrm{HCl}$, THF, rt, $4 \mathrm{~h}, 96 \%$; (ii) $\mathrm{BrCH}_{2} \mathrm{COCOOC}_{2} \mathrm{H}_{5}, \mathrm{KOH}, \mathrm{MeOH}, 12 \mathrm{~h}, 55 \%$; (iii) $\left(\mathrm{CH}_{3} \mathrm{COO}\right)_{3} \mathrm{Mn} \cdot 2 \mathrm{H}_{2} \mathrm{O}$, $\mathrm{PhC}^{\prime} \mathrm{CH}, \mathrm{AcOH}$, from 80 to $45^{\circ} \mathrm{C}, 2 \mathrm{~h}, 30 \%$; (iv) 2-chloroacetoacetate, $\mathrm{KOH}, \mathrm{MeOH}, \mathrm{H}_{2} \mathrm{O}, \mathrm{rt}, 36 \mathrm{~h}, 40 \%$; and (v) $\mathrm{CH}_{2} \mathrm{~N}_{2}, \mathrm{MeOH}, \mathrm{Et}_{2} \mathrm{O}, \mathrm{rt}, 12 \mathrm{~h}$, $97 \%$.

Scheme $5^{a}$
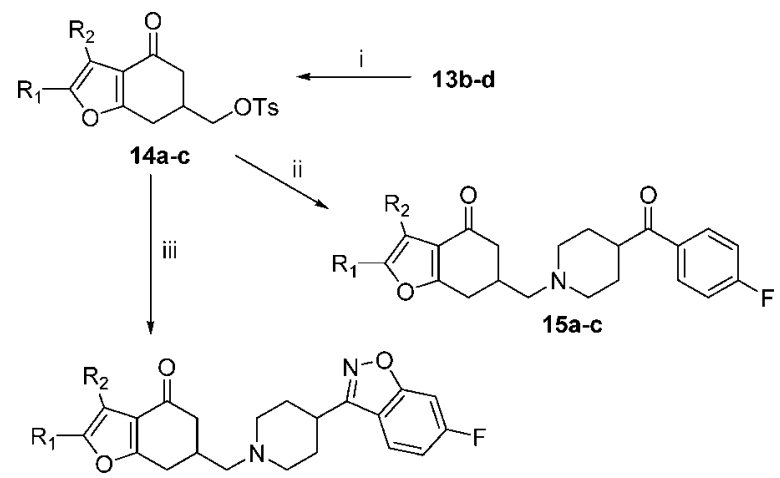

16a-c

${ }^{a}$ Reagents and conditions: (i) $\mathrm{TsCl}$, By, from $0{ }^{\circ} \mathrm{C}$ to rt, $24 \mathrm{~h}, 45-63 \%$; (ii) 4-(4-fluorobenzoyl)piperidine, $\mathrm{CH}_{3} \mathrm{CN}$, reflux, $22 \mathrm{~h}, 25-45 \%$; and (iii) 4-(6-fluorobenzisoxazol-3-yl)piperidine, $\mathrm{CH}_{3} \mathrm{CN}$, reflux, $24 \mathrm{~h}, 30-84 \%$.

approximately 1 order of magnitude, and the effect is even more remarkable for the $\mathrm{D}_{2}$ receptor, where the $\mathrm{FB}$ compounds show no affinity. The compounds can be ranked according to their binding affinities as follows: $\mathrm{BI}-5-\mathrm{HT}_{2 \mathrm{~A}}>\mathrm{BI}-\mathrm{D}_{2}$ and $\mathrm{FB}-5-$ $\mathrm{HT}_{2 \mathrm{~A}}>\mathrm{FB}-\mathrm{D}_{2}$.

A close analysis of the obtained complexes of our modeling studies suggests an interesting explanation of their binding- 


\section{Scheme $6^{a}$}

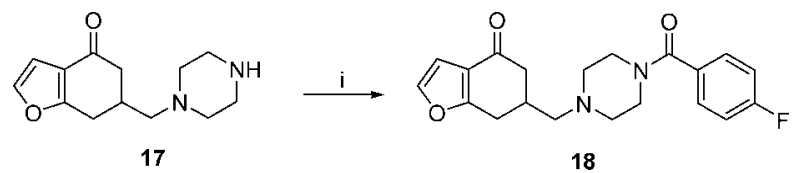

${ }^{a}$ Reagents and conditions: 4-fluorobenzoic acid, DCC, $\mathrm{HOBt}, \mathrm{CH}_{2} \mathrm{Cl}_{2}$, from $0{ }^{\circ} \mathrm{C}$ to $\mathrm{rt}, 45 \%$.

Table 2. Binding Profile of the Individual Enantiomers and the Racemic Mixture of 2 for the Dopamine $\mathrm{D}_{2}$ and Serotonins 5- $\mathrm{HT}_{2 \mathrm{~A}}$ and 5- $\mathrm{HT}_{2 \mathrm{C}}$ Receptors $^{a}$

\begin{tabular}{cccc}
\hline compd & $\mathrm{p} K_{\mathrm{i}} \mathrm{D}_{2}$ & $\mathrm{p} K_{\mathrm{i}} 5-\mathrm{HT}_{2 \mathrm{~A}}$ & $\mathrm{p} K_{\mathrm{i}} 5-\mathrm{HT}_{2 \mathrm{C}}$ \\
\hline$(+)-2$ & $7.38 \pm 0.15$ & $8.60 \pm 0.22$ & $6.61 \pm 0.15$ \\
$(-)-2$ & $7.80 \pm 0.10$ & $8.29 \pm 0.15$ & $6.43 \pm 0.22$ \\
$( \pm)-2$ & $7.79 \pm 0.18$ & $8.26 \pm 0.12$ & $6.47 \pm 0.26$ \\
\hline
\end{tabular}

${ }^{a}$ Data are expressed as mean \pm SEM of two experiments.

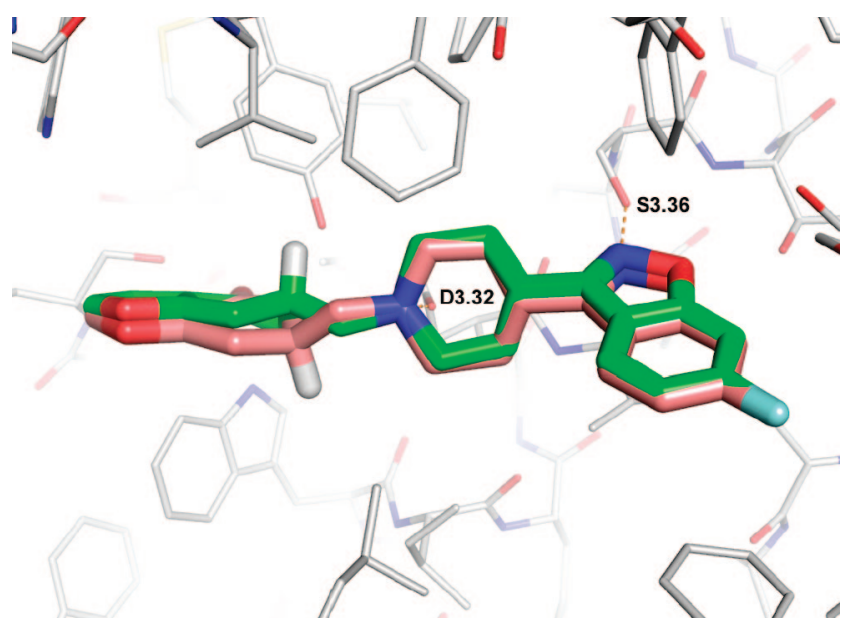

Figure 2. Superimposition of the docking solutions for the R and $\mathrm{S}$ enantiomers of compound 2 over the binding site of the 5-HT $2 \mathrm{~A}$ receptor.

affinity rankings. As shown in Figure 3, the main polar interactions between the ligand and the receptor at this part of the binding pocket are established between the $\mathrm{H}$-bond acceptor atoms of the $\mathrm{FB}$ or $\mathrm{BI}$ moieties and the $\mathrm{H}$-bond donor side chains of the amino acid residues at positions 3.36 and 5.46. The BI moiety contains two H-bond acceptors, and it can therefore establish two $\mathrm{H}$-bonds with the $5-\mathrm{HT}_{2 \mathrm{~A}}$ receptor (S3.36 and S5.46). This proposed forked interaction of the BI moiety that is simutaneously mediated by the nitrogen and oxygen heteroatoms is supported by experimental structural data. ${ }^{37-39}$ In the $D_{2}$ receptor, however, the serine at position 3.36 is replaced by a cysteine, and the ligand can establish only one strong $\mathrm{H}$-bond. The importance of these residues in the binding of antipsychotics has been shown in a previous recent study. ${ }^{40}$ The compounds of the FB series have only one H-bond acceptor group that is oriented toward residue 3.36 , which limits them to establishing a single $\mathrm{H}$-bond with the $5-\mathrm{HT}_{2 \mathrm{~A}}$ receptor and no strong $\mathrm{H}$-bonds with the $\mathrm{D}_{2}$ receptor. In addition, the entropic cost of fixing the more flexible FB moiety will probably contribute to the further reduction of the binding affinities of all of the compounds in this series. Overall, these differences in hydrogen bonding can explain the previously mentioned ranking of binding affinity: $\mathrm{BI}-5-\mathrm{HT}_{2 \mathrm{~A}}$ (two $\mathrm{H}$-bonds) $>\mathrm{BI}-\mathrm{D}_{2}$, and $\mathrm{FB}-5-\mathrm{HT}_{2 \mathrm{~A}}$ (one $\mathrm{H}$-bond) $>\mathrm{FB}-\mathrm{D}_{2}$ (no H-bonds). It should be emphasized that the quality of our structural models allows only a qualitative interpretation of the observed differences and not a complete quantitative description of individual binding affinities.
This raises the question of why the same affinities are not observed for compounds $\mathbf{1}$ and $\mathbf{2}$. Both are unsubstituted at the furan ring and are free of the bulky groups that are present for $\mathbf{1 5} \mathbf{a}-\mathbf{c}$ and $16 \mathbf{a}-\mathbf{c}$. Consequently, they are free to bind the receptors in an alternative orientation that interchanges the position of the molecule's ends at the binding site; in this alternative orientation, the interactions with the $5-\mathrm{HT}_{2 \mathrm{~A}}$ and $\mathrm{D}_{2}$ receptors are weaker. These results were confirmed by docking simulations, which yielded docking solutions in both orientations for only the unsubstituted compounds. The presence of two alternative binding modes for this series of compounds has been previously reported, ${ }^{36,41}$ and it is consistent with both molecular modeling and experimental results.

The 4-( $p$-fluorobenzoyl)piperidine fragment has been described as an antipsychotic pharmacophore with a potency that is similar to that of linear butyrophenones, ${ }^{42}$ and a SAR study of ketanserin analogs has suggested that the carbonyl of the benzoyl moiety (present in $\mathbf{1}, \mathbf{3}$, and $\mathbf{1 5 a}-\mathbf{c}$ ) may be important for the anchoraging or the orientation in the 5- $\mathrm{HT}_{2 \mathrm{~A}}$ receptor's binding site. ${ }^{43}$ To determine whether this carbonyl's identity as a ketone group is essential for binding, we synthesized an amide analog. The resultant benzoylpiperazine derivative $\mathbf{1 8}$ (Table 4) bound to the $5-\mathrm{HT}_{2 \mathrm{~A}}$ receptor with 10 -fold lower affinity than that for analog $\mathbf{1}$. Furthermore, the substitution of the piperidine ring with a pirerazine ring in these compounds drastically reduces the binding affinity for both dopamine $\mathrm{D}_{2}$ and serotonin $5-\mathrm{HT}_{2 \mathrm{C}}$ receptors.

Again, the experimental results may be rationalized on the basis of the structures of the complexes that were obtained by modeling studies. In compound $\mathbf{1 8}$, the carbonyl oxygen is part of the planar amide group that orients this oxygen in a way that prevents it from interacting with the aforementioned S3.36 residue. Figure 4 shows a superposition of compounds $\mathbf{1}$ and 18 bound to the $5-\mathrm{HT}_{2 \mathrm{~A}}$ receptor. The superposition reveals the different abilities of the two compounds to interact with S3.36.

\section{Conclusions}

Butyrophenone analogs with benzofuranone cores were prepared and examined here for their affinities and selectivities as $5-\mathrm{HT}_{2 \mathrm{~A}} / \mathrm{D}_{2}$ dual ligands. The SAR study focused on the chirality and substitutions of the piperidine ring and the benzofuranone core. The use of almost enantiopure compounds indicated that the chirality of the compounds in this series does not influence their affinity or the selectivity for the studied receptors. This finding is supported by both experimental and molecular docking studies. For example, the docking studies showed that both enantiomers can establish the same polar interactions in the receptor binding site. Compound 16a shows the greatest potential for antipsychotic activity. It binds with moderate-to-high affinities for the $\mathrm{D}_{2}$ and $5-\mathrm{HT}_{2 \mathrm{~A}}$ receptors with an appropriate affinity ratio at these two receptors for atypicality; further work is needed to assess its effect in animal models of schizophrenia. Because they show a range of affinity for this receptor, these compounds stand out as useful pharmacological tools in the elucidation of the role of the $5-\mathrm{HT}_{2 \mathrm{C}}$ receptor in antipsychotic efficacy and metabolic side effects.

Apart from the usefulness of the new compounds, the modeling reported here provides a rationalization for the extreme differences in the binding affinities observed in some compounds with respect to the $5-\mathrm{HT}_{2 \mathrm{~A}}$ and $\mathrm{D}_{2}$ receptors. These differences seem to be related to the presence of either the 4-benzoylpiperidine (15 series) or the 4-benzisoxazolylpiperidine (16 series) moieties. The differences can be explained in terms of their abilities to establish key polar 
Table 3. Binding Profile of the Aminoalkylbenzofuranone Derivatives 15a-c, 16a-c (Scheme 2), 1, and 2 and Reference Compounds at the Dopamine $\mathrm{D}_{2}$ and Serotonin 5- $\mathrm{HT}_{2 \mathrm{~A}}$ and 5-HT2C Receptors ${ }^{a}$

\begin{tabular}{|c|c|c|c|c|c|c|}
\hline compd & R1 & $\mathrm{R} 2$ & $\mathrm{p} K_{\mathrm{i}} \mathrm{D}_{2}$ & $\mathrm{p} K_{\mathrm{i}} 5-\mathrm{HT}_{2 \mathrm{~A}}$ & $\mathrm{p} K_{\mathrm{i}} 5-\mathrm{HT}_{2 \mathrm{C}}$ & $\mathrm{MR}^{b}$ \\
\hline 15a (QF1014B) & $\mathrm{H}$ & $\mathrm{CO}_{2} \mathrm{Me}$ & $<5$ & $7.59 \pm 0.23$ & $<5$ & \\
\hline 15b (QF1064B) & $\mathrm{Ph}$ & $\mathrm{H}$ & $<5$ & $7.76 \pm 0.27$ & $<5$ & \\
\hline 15c (QF1034B) & $\mathrm{CO}_{2} \mathrm{Et}$ & $\mathrm{Me}$ & $<5$ & $7.66 \pm 0.14$ & $<5$ & \\
\hline 16b (QF1068B) & $\mathrm{Ph}$ & $\mathrm{H}$ & $7.92 \pm 0.15$ & $8.16 \pm 0.18$ & 5.48 & 1.03 \\
\hline 16c (QF1038B) & $\mathrm{CO}_{2} \mathrm{Et}$ & $\mathrm{Me}$ & $6.67 \pm 0.14$ & $8.08 \pm 0.50$ & $<5$ & 1.21 \\
\hline 1 (QF1003B) & $\mathrm{H}$ & $\mathrm{H}$ & $6.82 \pm 0.17$ & $7.02 \pm 0.14$ & $5.81 \pm 0.21$ & 1.03 \\
\hline 2 (QF1004B) & $\mathrm{H}$ & $\mathrm{H}$ & $7.79 \pm 0.18$ & $8.26 \pm 0.12$ & $6.47 \pm 0.26$ & 1.06 \\
\hline
\end{tabular}

${ }^{a}$ Data are expressed as mean \pm SEM of two experiments. ${ }^{b} \mathrm{MR}=$ Meltzer ratio $\left(\mathrm{p} K_{\mathrm{i}} 5-\mathrm{HT}_{2 \mathrm{~A}} / \mathrm{p} K_{\mathrm{i}} \mathrm{D}_{2}\right)$.

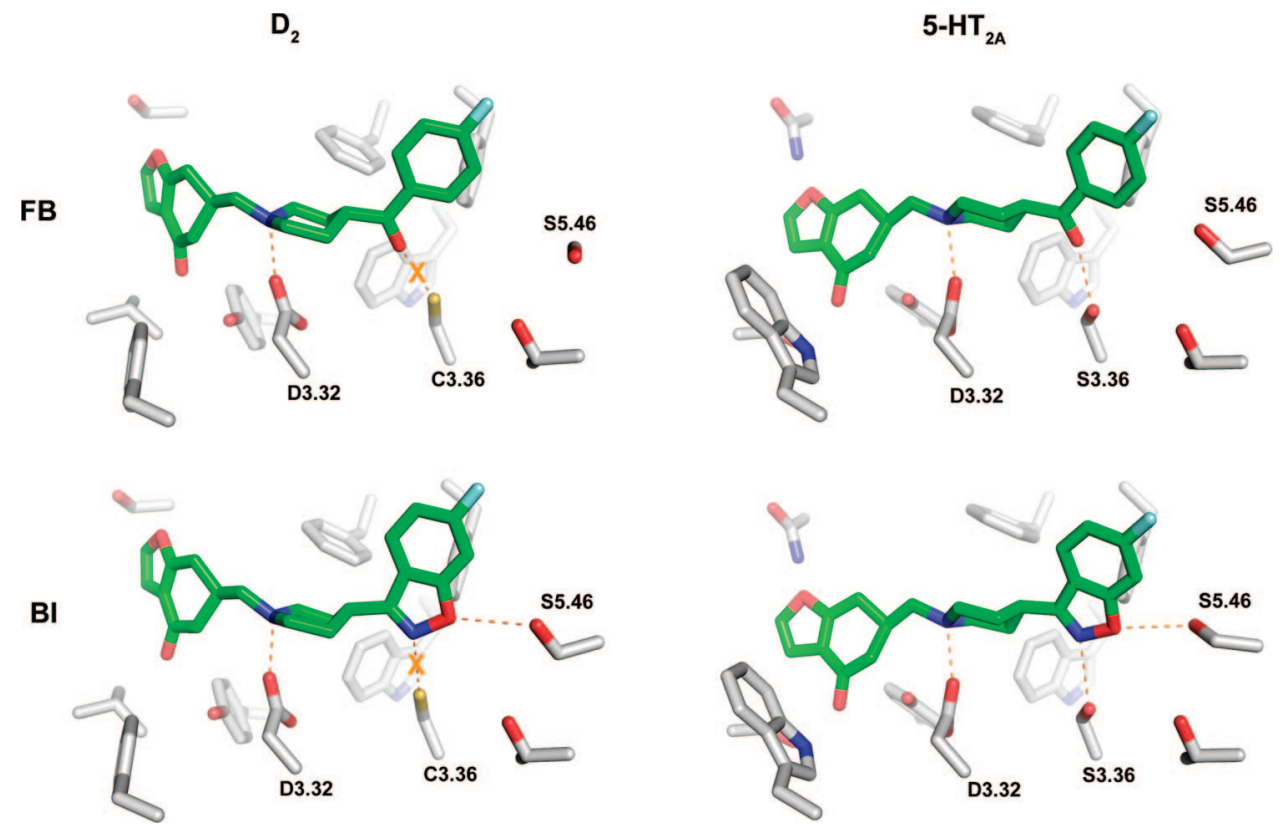

Figure 3. Structures of the $\mathrm{D}_{2}$ and 5- $\mathrm{HT}_{2 \mathrm{~A}}$ receptors complexed with compounds bearing $p$-fluorobenzoyl (FB) and 6-fluorobenzisoxazolyl (BI) moieties. FB compounds cannot establish strong H-bonds with the residues at positions 3.36 and 5.46 of the $\mathrm{D}_{2}$ receptor, and they can establish only one $\mathrm{H}$-bond with the same residues of the $5-\mathrm{HT}_{2 \mathrm{~A}}$ receptor. In contrast, the $\mathrm{BI}$ compounds can establish one $\mathrm{H}$-bond and two $\mathrm{H}-$ bonds with the same receptors, respectively. See the text for details.

Table 4. Effects the Substitution of the Benzoylpiperidine Moiety with a Benzoylpiperazine (1 vs 18) on Receptor Binding Affinity ${ }^{a}$

\begin{tabular}{lccc}
\hline \multicolumn{1}{c}{ compd } & $\mathrm{p} K_{\mathrm{i}} \mathrm{D}_{2}$ & $\mathrm{p} K_{\mathrm{i}} 5-\mathrm{HT}_{2 \mathrm{~A}}$ & $\mathrm{p} K_{\mathrm{i}} 5-\mathrm{HT}_{2 \mathrm{C}}$ \\
\hline $\mathbf{1}(\mathrm{QF} 1003 \mathrm{~B})$ & $6.82 \pm 0.17$ & $7.02 \pm 0.14$ & $5.81 \pm 0.21$ \\
$\mathbf{1 8}(\mathrm{QF1012B})$ & $<5$ & $5.88 \pm 0.46$ & $<5$ \\
\hline
\end{tabular}

${ }^{a}$ Data are expressed as mean \pm SEM of two experiments.

interactions with the residues at positions 3.36 and 5.46 in both receptors. This hypothesis deserves further experimental confirmation by synthesizing and testing derivatives with alternative $\mathrm{H}$-bond patterns that confirm the importance of these residues in the overall ligand selectivity. The finding presented in this work may prove useful in the future design of selective compounds for either the previously mentioned receptors or the other receptors involved in the treatment of schizophrenia. The fact that our modeling studies concur with experimental work in explaining binding selectivity as well as other minor findings (such as the low activity of compound 18) argues for the accuracy and usefulness of our homology modeling approach.

On the basis of our present study, our aminomethylbenzofuranones have provided new insights into the binding mode of ligands to the $\mathrm{D}_{2}$ and $5-\mathrm{HT}_{2 \mathrm{~A}}$ receptors and have thereby contributed to this very active research area. Work is underway to develop these compounds further into pharmacological tools for the study of binding sites on these and other receptors. This research may lead to the design of new chemical agents that show an optimal affinity profile and that avoid the adverse side effects that are associated with the dibenzodiazepine structure of clozapine.

\section{Experimental Section}

Chemistry. Melting points were determined with a Kofler hot stage instrument or a Gallenkamp capillary melting point apparatus and are uncorrected. Infrared spectra were recorded with a PerkinElmer 1600 FTIR spectrophotometer; the main bands are given in $\mathrm{cm}^{-1}$. ${ }^{1} \mathrm{H}$ NMR spectra were recorded on a Bruker WM AMX (300 MHz) spectrometer; chemical shifts were recorded in parts per million $(\delta)$ downfield from tetramethylsilane (TMS). Mass spectra were performed on a Kratos MS-50 or a Varian Mat-711 mass spectrometer by chemical ionization (CI) or by electron impact (EI) methods. We performed flash column chromatography by using Kieselgel 60 (60-200 mesh, E. Merck AG, Darmstadt, Germany). We monitored the reactions by thin layer chromatography (TLC) on Merck 60 GF254 chromatogram sheets using iodine vapor, UV light, or both for detection. Unless otherwise stated, each purified compound showed a single spot. HPLC analysis was performed on a Waters HPLC system that consisted of a vacuum degasser, a binary pump, a column compartment, and a UV detector (254 and $330 \mathrm{~nm}$ ). Chiral HPLC was carried out at room temperature on a Chiralcel OD-H column (Daicel Chemical Industries, Japan). 


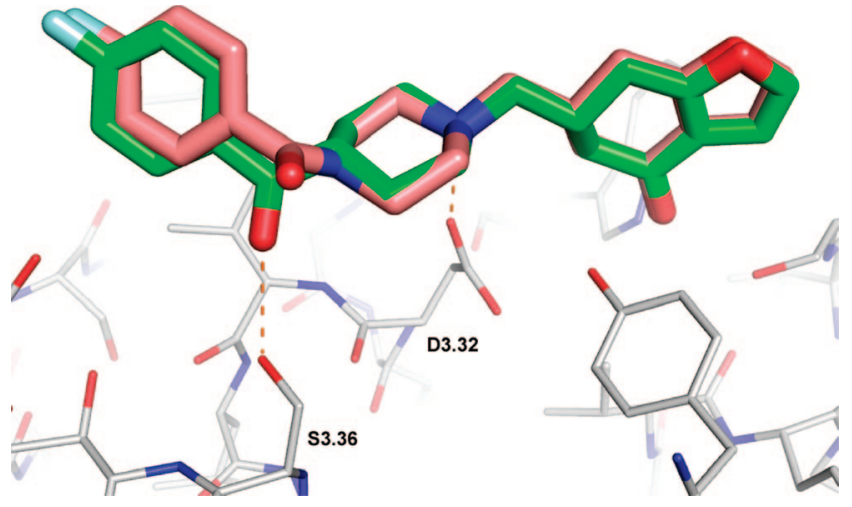

Figure 4. Modeled complexes of receptor $5-\mathrm{HT}_{2 \mathrm{~A}}$ with compounds $\mathbf{1}$ (carbons in green) and $\mathbf{1 8}$ (carbons in pink). The planar amide group present in $\mathbf{1 8}$ prevents any H-bonding between the amide carbonilic oxygen and S3.36, such as the H-bond shown here for $\mathbf{1}$.

Elemental combustion analyses were performed by the Microanalysis Service of the University of Santiago de Compostela on a PerkinElmer 240B apparatus. Unless otherwise stated, all reported values were within $\pm 0.4 \%$ of the theoretical compositions. Solvents were purified by distillation over an appropriate drying agent under an argon atmosphere and were immediately used. Diazomethane solution was prepared according to Vogel. ${ }^{44}$

Enzymatic Resolution of ( \pm )-6-(Hydroxymethyl)-4,5,6,7-tetrahydro-1-benzofuran-4-one $(( \pm)-5)$. To a solution of the hydroxymethylbenzofuranone $( \pm)-\mathbf{5}^{30}(226 \mathrm{mg}, 1.35 \mathrm{mmol})$ in benzene $(12 \mathrm{~mL})$ were added vinyl acetate $(82 \mu \mathrm{L}, 0.84 \mathrm{mmol})$ and PF lipase on Celite $(136 \mathrm{mg})$. The mixture was stirred for $70 \mathrm{~h}$ at room temperature, was filtered through Celite, and was concentrated in vacuo. The residue was purified by column chromatography with 1:3 AcOEt/hexane as the eluent to give $(R)-3$ hydroxymethylbenzofuranone $((-)-5)(68 \mathrm{mg}, 30 \%)$ and the $(S)-$ acetate $(+)-6(62 \mathrm{mg}, 22 \%)$ as a yellowish oil.

(R)-6-(Hydroxymethyl)-4,5,6,7-tetrahydro-1-benzofuran-4one, (-)-5. The spectroscopic data were identical to those of the racemic compound. ${ }^{30}[\alpha]_{\mathrm{D}}^{20}=-45.0$ (c 2.5, AcOEt). 99\% ee. Chiralcel OD-H; hexane/2-propanol, 93:7; flow, $0.4 \mathrm{~mL} / \mathrm{min} ; \lambda=$ $254 \mathrm{~nm} ; t_{\mathrm{R}}=99.6 \mathrm{~min}$.

(S)-(4-Oxo-4,5,6,7-tetrahydro-1-benzofuran-6-yl)methyl Acetate, (+)-6. IR: 1733, 1683, 1246, 1039. ${ }^{1} \mathrm{H}$ NMR $(\delta): 2.08\left(\mathrm{~s}, 3 \mathrm{H}, \mathrm{CH}_{3}\right)$, $2.34-2.43\left(\mathrm{~m}, 1 \mathrm{H}, \mathrm{H}_{5}\right), 2.58-2.78\left(\mathrm{~m}, 3 \mathrm{H}, 1 \mathrm{H}_{5}, \mathrm{H}_{6}, 1 \mathrm{H}_{7}\right)$, 2.98-3.08 (m, 1H, $\left.1 \mathrm{H}_{7}\right), 4.09-4.17\left(\mathrm{~m}, 2 \mathrm{H}, \mathrm{CH}_{2}-\mathrm{OAc}\right), 6.67$ (d, $\left.1 \mathrm{H}, J=1.9 \mathrm{~Hz}, \mathrm{H}_{3}\right), 7.34\left(\mathrm{~d}, 1 \mathrm{H}, J=1.8 \mathrm{~Hz}, \mathrm{H}_{2}\right)$. EIMS $m / z: 208$ $\left(\mathrm{M}^{+}\right) .[\alpha]_{\mathrm{D}}^{25}=+41.7$ ( c 2.6, AcOEt). 99\% ee. Chiralcel OD-H; hexane/2-propanol, 93:7; flow, $0.4 \mathrm{~mL} / \mathrm{min} ; \lambda=254 \mathrm{~nm} ; t_{\mathrm{R}}=78.1$ $\min$.

(S)-6-(Hydroxymethyl)-4,5,6,7-tetrahydro-1-benzofuran-4-one (+)5. To a solution of acetate $(S)-(+)-6(188 \mathrm{mg}, 0.90 \mathrm{mmol})$ in dimethoxyethane $(10 \mathrm{~mL})$ was added $1 \mathrm{~N}$ aqueous $\mathrm{LiOH}(2.26 \mathrm{~mL}$, $2.26 \mathrm{mmol}$ ). The mixture was refluxed for $13 \mathrm{~h}, 1 \mathrm{~N}$ aqueous $\mathrm{LiOH}$ $(1.36 \mathrm{~mL}, 1.36 \mathrm{mmol})$ was added, and the mixture was heated for $4 \mathrm{~h}$. After cooling to room temperature, the reaction mixture was diluted with $\mathrm{Et}_{2} \mathrm{O}(25 \mathrm{~mL})$ and acidified with $1 \mathrm{~N} \mathrm{HCl}$. The organic phase was separated, and the aqueous layer was extracted with ether. The combined organic extracts were dried $\left(\mathrm{Na}_{2} \mathrm{SO}_{4}\right)$ and concentrated in vacuo to give a residue that was purified by column chromatography with $4: 1$ AcOEt/hexane as the eluent. The title compound (117 mg, 78\%) was yielded as a white solid. The spectroscopic data were identical to those of the racemic compound. ${ }^{30}[\alpha]_{\mathrm{D}}^{25}=+45.1$ ( $c$ 2.4; AcOEt). 99\% ee. Chiralcel OD-H; hexane/2-propanol, 93:7; flow, $0.4 \mathrm{~mL} / \mathrm{min} ; \lambda=254 \mathrm{~nm} ; t_{\mathrm{R}}=94.1$ $\min$.

(S)-6-(Bromomethyl)-4,5,6,7-tetrahydro-1-benzofuran-4-one, $(S)$ 7. A stirred solution of alcohol $(S)-5$ (160 mg, $0.96 \mathrm{mmol})$, carbon tetrabromide ( $400 \mathrm{~g}, 1.2 \mathrm{mmol}$ ), and triphenyl phosphine (380 mg, $1.44 \mathrm{mmol})$ in $\mathrm{CH}_{2} \mathrm{Cl}_{2}(10 \mathrm{~mL})$ was refluxed under argon for $28 \mathrm{~h}$. After cooling, the reaction mixture was washed with $5 \% \mathrm{NaHCO}_{3}$ and water, the organic phase was dried $\left(\mathrm{Na}_{2} \mathrm{SO}_{4}\right)$, and the solvent was distilled off. Purification of the residue by column chromatography with 1:2 AcOEt/hexane as the eluent gave the title compound $(210 \mathrm{mg}, 95 \%)$ as a white solid. $\mathrm{mp} 59-60^{\circ} \mathrm{C}$. IR: 3139 , $1675,1450,1121 .{ }^{1} \mathrm{H}$ NMR $\left(\mathrm{CDCl}_{3}, \delta\right): 2.50(\mathrm{dd}, 1 \mathrm{H}, J=16.3$, $\left.11.5 \mathrm{~Hz}, \mathrm{H}_{5}\right), 2.61-2.76\left(\mathrm{~m}, 2 \mathrm{H}, \mathrm{H}_{5}, \mathrm{H}_{6}\right), 2.85$ (dd, $1 \mathrm{H}, J=16.7$, $\left.10.0 \mathrm{~Hz}, \mathrm{H}_{7}\right), 3.14\left(\mathrm{dd}, 1 \mathrm{H}, J=16.8,5.1 \mathrm{~Hz}, \mathrm{H}_{7}\right), 6.68(\mathrm{~d}, 1 \mathrm{H}, J$ $\left.=2.0 \mathrm{~Hz}, \mathrm{H}_{3}\right), 7.35\left(\mathrm{~d}, 1 \mathrm{H}, J=2.0 \mathrm{~Hz}, \mathrm{H}_{2}\right)$. CIMS m/z: $229\left(\mathrm{MH}^{+}\right)$, $231\left[(\mathrm{MH}+2)^{+}\right] .[\alpha]_{\mathrm{D}}^{25}=+43.5\left(c 2.0, \mathrm{CHCl}_{3}\right) .97 \%$ ee. Chiralcel OD-H; hexane/2-propanol, 93:7; flow, $0.4 \mathrm{~mL} / \mathrm{min} ; \lambda=254 \mathrm{~nm}$; $t_{\mathrm{R}}=74.5 \mathrm{~min}$.

(R)-6-(Bromomethyl)-4,5,6,7-tetrahydro-1-benzofuran-4-one, $(R)$ 7. The title compound was prepared according to the above procedure, starting from the alcohol $(R)-5 .[\alpha]_{\mathrm{D}}^{25}=-44.6(c 0.7$, $\mathrm{CHCl}_{3}$ ). 99\% ee. Chiralcel OD-H; hexane/2-propanol, 93:7; flow, $0.4 \mathrm{~mL} / \mathrm{min} ; \lambda=254 \mathrm{~nm} ; t_{\mathrm{R}}=70.5 \mathrm{~min}$.

General Procedure for the Preparation of 6-(Aminomethyl)4,5,6,7-tetrahidro-1-benzofuran-4-ones $(R)$ - and $(S)-1-2$. To a solution of $(R)$ - or $(S)$-bromobenzofuranone 7 (100 $\mathrm{mg}, 0.44 \mathrm{mmol}$ ) and the appropriate amine $(0.90 \mathrm{mmol})$ was stirred in $N$-methyl2-pyrrolidone $(5 \mathrm{~mL})$ for $16 \mathrm{~h}$ at $85^{\circ} \mathrm{C}$. The solvent was removed in vacuo, and the residue was dissolved in $\mathrm{CH}_{2} \mathrm{Cl}_{2}$. This solution was washed twice with water and was dried $\left(\mathrm{Na}_{2} \mathrm{SO}_{4}\right)$, and the solvent was removed in vacuo, which afforded an orange solid that upon column chromatography with AcOEt as the eluent gave the final amine as a white crystalline solid. The spectroscopic data were identical to those of the racemic compounds. ${ }^{30}$

$(R)-6-\{[4-(p$-Fluorobenzoyl)piperidin-1-yl]methyl $\}-4,5,6,7-$ tetrahydro-1-benzofuran-4-one, $(\boldsymbol{R})-\mathbf{1}$. The title compound was prepared in $70 \%$ yield according to the general procedure using $4-(p$ fluorobenzoyl)piperidine as the amine. $[\alpha]_{\mathrm{D}}^{25}=-37.9$ ( $c 0.68$, AcOEt). Hydrochloride: Anal. Calcd $\left(\mathrm{C}_{21} \mathrm{H}_{22} \mathrm{FNO}_{3} \cdot \mathrm{HCl} \cdot 1.5 \mathrm{H}_{2} \mathrm{O}\right)$ : $\mathrm{C}, \mathrm{H}, \mathrm{N}$.

(S)-6-\{[4-(p-Fluorobenzoyl)piperidin-1-yl $]$ methyl $\}-4,5,6,7-$ tetrahydro-1-benzofuran-4-one, $(\boldsymbol{S})-\mathbf{1}$. The title compound was prepared in $65 \%$ yield according to the general procedure using $4-(p-$ fluorobenzoyl)piperidine as the amine. $[\alpha]_{\mathrm{D}}^{25}=+33.4$ ( $c 0.40$, AcOEt). Hydrochloride: Anal. Calcd $\left(\mathrm{C}_{21} \mathrm{H}_{22} \mathrm{FNO}_{3} \cdot \mathrm{HCl} \cdot 0.6 \mathrm{H}_{2} \mathrm{O}\right)$ : C, H, N.

(R)-6-\{[4-(6-Fluorobenzisoxazol-3-yl)piperidin-1-yl]methyl\}-4,5,6,7-tetrahydro-1-benzofuran-4-one, $(R)-2$. The title compound was prepared in $62 \%$ yield according to the general procedure using 4-(6-fluorobenzisoxazol-3-yl)piperidine as the amine. $[\alpha]_{\mathrm{D}}^{25}$ $=-31.6$ ( $c$ 1.65, AcOEt). Hydrochloride: Anal. Calcd $\left(\mathrm{C}_{21} \mathrm{H}_{21} \mathrm{FN}_{2^{-}}\right.$ $\left.\mathrm{O}_{3} \cdot \mathrm{HCl} \cdot 0.2 \mathrm{H}_{2} \mathrm{O}\right): \mathrm{C}, \mathrm{H}, \mathrm{N}$.

(S)-6-\{[4-(6-Fluorobenzisoxazol-3-yl)piperidin-1-yl]methyl\}-4,5,6,7tetrahydro-1-benzofuran-4-one, $(\boldsymbol{S})-\mathbf{2}$. The title compound was prepared in $65 \%$ yield according to the general procedure using 4-(6-fluorobenzisoxazol-3-yl)piperidine as the amine. $[\alpha]_{\mathrm{D}}^{25}=+29.6$ (c 0.46, AcOEt). Hydrochloride: Anal. Calcd $\left(\mathrm{C}_{21} \mathrm{H}_{21} \mathrm{FN}_{2} \mathrm{O}_{3} \cdot 2 \mathrm{H}-\right.$ $\left.\mathrm{Cl} \cdot 0.1 \mathrm{H}_{2} \mathrm{O}\right): \mathrm{C}, \mathrm{H}, \mathrm{N}$.

tert-Butyl-(S)-4-(furan-2-yl)-3-(hydroxymethyl)butanoate, $(S)$ 9. To a solution of hemiester $(S)-8(102 \mathrm{mg}, 0.4 \mathrm{mmol})$ in anhydrous THF $(5 \mathrm{~mL})$ cooled in an ice bath was added borane dimethyl sulfide complex $(0.058 \mathrm{~mL}, 0.61 \mathrm{mmol})$ dropwise. The reaction mixture was stirred at $0{ }^{\circ} \mathrm{C}$ for $15 \mathrm{~min}$ and then at room temperature for $2 \mathrm{~h}$. After the mixture was cooling again in an ice bath, methanol was added dropwise until effervescence ceased, and then the mixture was stirred at room temperature for $1 \mathrm{~h}$. The solvent was then evaporated under vacuum, and the crude oil was purified by column chromatography with $8: 1 \mathrm{AcOEt} /$ hexane as the eluent to give the title compound (84 mg, 86\%) as a yellowish oil. IR: 3424, 2976, 1724, 1151. ${ }^{1} \mathrm{H}$ NMR $\left(\mathrm{CDCl}_{3}, \delta\right): 1.44\left(\mathrm{~s}, 9 \mathrm{H}, \mathrm{C}\left(\mathrm{CH}_{3}\right)_{3}\right), 2.27-2.71$ $\left(\mathrm{m}, 3 \mathrm{H}, \mathrm{H}_{2}, \mathrm{H}_{3}\right), 2.63-2.73\left(\mathrm{~m}, 2 \mathrm{H}\right.$, furan- $\left.\mathrm{CH}_{2}\right), 3.53$ (dd, $1 \mathrm{H}, J=$ $11.0,5.4 \mathrm{~Hz},-\mathrm{HCH}-\mathrm{OH}), 3.61(\mathrm{dd}, 1 \mathrm{H}, J=11.1,4.7 \mathrm{~Hz}$, $-\mathrm{HCH}-\mathrm{OH}), 6.04\left(\mathrm{~d}, 1 \mathrm{H}, J=3.1 \mathrm{~Hz}, \mathrm{H}_{3}\right.$ furan), 6.28 (dd, $1 \mathrm{H}, J$ $=3.0,1.9 \mathrm{~Hz}, \mathrm{H}_{4}$ furan), $7.30\left(\mathrm{~d}, 1 \mathrm{H}, J=1.5 \mathrm{~Hz}, \mathrm{H}_{5}\right.$ furan). CIMS $\mathrm{m} / \mathrm{z}: 241\left(\mathrm{MH}^{+}\right) .[\alpha]_{\mathrm{D}}^{25}=+1.32\left(c 2.8 ; \mathrm{CH}_{2} \mathrm{Cl}_{2}\right)$.

(S)-4-[(2-Furyl)methyl]-2,3,4,5-tetrahydrofuran-2-one, $(S)-10$. A solution of the hydroxyester $(S)-9(1.0 \mathrm{~g}, 4.16 \mathrm{mmol})$ and $p$-TsOH (catalytic) in benzene $(25 \mathrm{~mL})$ was refluxed under argon for $3 \mathrm{~h}$. 
After cooling to room temperature, the solution was washed with $10 \% \mathrm{NaHCO}_{3}$ and water. Aqueous phases were extracted with AcOEt, and the combined organic extracts were dried $\left(\mathrm{Na}_{2} \mathrm{SO}_{4}\right)$ and concentrated in vacuo. The residue was purified by column chromatography with $5 \% \mathrm{MeOH} / \mathrm{CH}_{2} \mathrm{Cl}_{2}$ as the eluent to give the title compound $(0.53 \mathrm{~g}, 76 \%)$ as a yellowish oil. IR: 1775,1170 , 1008. ${ }^{1} \mathrm{H}$ NMR $\left(\mathrm{CDCl}_{3}, \delta\right): 2.31\left(\mathrm{dd}, 1 \mathrm{H}, J=17.6,6.8 \mathrm{~Hz}, 1 \mathrm{H}_{3}\right)$, $2.65\left(\mathrm{dd}, 1 \mathrm{H}, J=17.6,8.2 \mathrm{~Hz}, 1 \mathrm{H}_{3}\right), 2.79(\mathrm{~d}, 2 \mathrm{H}, J=7.3 \mathrm{~Hz}$, furyl- $\left.\mathrm{CH}_{2}-\right), 2.84-2.96\left(\mathrm{~m}, 1 \mathrm{H}, \mathrm{H}_{4}\right), 4.07(\mathrm{dd}, 1 \mathrm{H}, J=9.2,6.0$ $\left.\mathrm{Hz}, 1 \mathrm{H}_{5}\right), 4.40\left(\mathrm{dd}, 1 \mathrm{H}, J=9.2,7.1 \mathrm{~Hz}, 1 \mathrm{H}_{5}\right), 6.06(\mathrm{~d}, 1 \mathrm{H}, J=3.3$ $\mathrm{Hz}, \mathrm{H}_{3}$ furan), 6.29 (dd, $1 \mathrm{H}, J=3.2,1.9 \mathrm{~Hz}, \mathrm{H}_{4}$ furan), 7.30 (d, $1 \mathrm{H}, J=1.7 \mathrm{~Hz}, \mathrm{H}_{5}$ furan). EIMS $m / z: 166\left(\mathrm{M}^{+}\right) .[\alpha]_{\mathrm{D}}^{24}=-5.76(c$ $\left.1.15 ; \mathrm{CH}_{2} \mathrm{Cl}_{2}\right)$.

(S)-6-(Bromomethyl)-4,5,6,7-tetrahydro-1-benzofuran-4-one, $(S)$ 7. To a solution of lactone $(S)-\mathbf{1 0}(0.59 \mathrm{~g}, 3.05 \mathrm{mmol})$ in glacial acetic acid $(7.5 \mathrm{~mL})$ cooled in an ice bath was added a $33 \%$ solution of $\mathrm{HBr}$ in acetic acid $(1 \mathrm{~mL}, 4.57 \mathrm{mmol})$. The mixture was heated to $80^{\circ} \mathrm{C}$ and was stirred at this temperature for $6 \mathrm{~h}$. After cooling to room temperature, the mixture was poured onto crushed ice and extracted with $\mathrm{CH}_{2} \mathrm{Cl}_{2}$. The organic extracts were washed with water, were dried $\left(\mathrm{Na}_{2} \mathrm{SO}_{4}\right)$, and were concentrated under reduced pressure to afford crude (S)-3-(bromomethyl)-4-(2-furyl)butanoic acid $(0.77 \mathrm{~g})$ as a yellowish oil, which was used without further purification. IR: 2924, 1710, 1430, 1250. IEMS m/z: $246\left(\mathrm{M}^{+}\right)$, $248\left[(\mathrm{M}+2)^{+}\right]$. A mixture of this compound $(380 \mathrm{mg}, 1.53 \mathrm{mmol})$, trifluoroacetic anhydride $(8.3 \mathrm{~mL})$, and trifluoroacetic acid $(1.6 \mathrm{~mL})$ was stirred under an argon atmosphere overnight at rt. The brown mixture was then poured onto crushed ice and extracted with $\mathrm{CH}_{2} \mathrm{Cl}_{2}$. The organic extracts were washed successively with icecold 5\% sodium hydroxide solution and brine and were then dried $\left(\mathrm{Na}_{2} \mathrm{SO}_{4}\right)$ and concentrated. The crude material obtained was purified by column chromatography with 1:2 EtOAc/hexane as the eluent to give the title compound (35 $\mathrm{mg}, 10 \%$ ) as a beige solid. Spectroscopic data were identical to those of the aforementioned compound. $[\alpha]_{\mathrm{D}}^{25}=+38\left(c 0.27, \mathrm{CHCl}_{3}\right) .85 \%$ ee. Chiralcel OD$\mathrm{H}$; hexane/2-propanol, 93:7; flow, $0.4 \mathrm{~mL} / \mathrm{min} ; \lambda=254 \mathrm{~nm} ; t_{\mathrm{R}}=$ $75.6 \mathrm{~min}$.

6-(Hydroxymethyl)-4-oxo-4,5,6,7-tetrahydro-1-benzofuran-3carboxylic Acid (13a). A solution of alcohol $\mathbf{1 1}^{32}$ (2.0 g, $\left.11.7 \mathrm{mmol}\right)$ in a mixture of THF $(50 \mathrm{~mL})$ and $1 \mathrm{~N} \mathrm{HCl}(10 \mathrm{~mL})$ was stirred at room temperature for $4 \mathrm{~h}$ and was then concentrated in vacuo, giving $1.6 \mathrm{~g}$ of a yellow oil that was identified as the hydroxydiketone $\mathbf{1 2}$ and was used without further purification in the next step, as follows. A solution of $\mathbf{1 2}(834 \mathrm{mg}, 5.86 \mathrm{mmol})$ in methanol $(2 \mathrm{~mL})$ was added with stirring to a mixture of $\mathrm{KOH}(328 \mathrm{mg}$, $5.86 \mathrm{mmol})$ in methanol $(3 \mathrm{~mL})$ that was maintained at $0-5{ }^{\circ} \mathrm{C}$. The mixture was basified until it reached $\mathrm{pH} 11$ by the addition of a $5 \mathrm{M}$ solution of $\mathrm{KOH}$ in methanol, and then ethyl 2-bromopiruvate $(0.77 \mathrm{~mL}, 6.15 \mathrm{mmol})$ was added at a rate of $0.4 \mathrm{~mL} / \mathrm{min}$. Stirring was continued at room temperature for $12 \mathrm{~h}, 60 \% \mathrm{NaOH}$ aqueous solution $(0.60 \mathrm{~mL})$ was added, and the mixture was left to stand at room temperature for $15 \mathrm{~h}$. After it was acidified by concentrated $\mathrm{HCl}$, the mixture was left to crystallize at $+4{ }^{\circ} \mathrm{C}$ in a refrigerator for 2 days. The precipitated solid was collected by filtration to afford the title compound $(683 \mathrm{mg}, 55 \%)$ as a yellowish solid. $\mathrm{mp}$ 164-165 ${ }^{\circ} \mathrm{C}$. IR: $3465,1701,1616,1547 .{ }^{1} \mathrm{H}$ NMR $\left(\mathrm{CD}_{3} \mathrm{OD}, \delta\right)$ : $2.64-2.80\left(\mathrm{~m}, 3 \mathrm{H}, \mathrm{H}_{5}, \mathrm{H}_{6}\right), 2.92\left(\mathrm{dd}, 1 \mathrm{H}, J=17.4,10.3 \mathrm{~Hz}, 1 \mathrm{H}_{7}\right)$, $3.05\left(\mathrm{dd}, 1 \mathrm{H}, J=17.6,4.7 \mathrm{~Hz}, 1 \mathrm{H}_{7}\right), 3.68-3.71\left(\mathrm{~m}, 2 \mathrm{H}, \mathrm{CH}_{2}-\mathrm{OH}\right)$, $8.30\left(\mathrm{~s}, 1 \mathrm{H}, \mathrm{H}_{2}\right)$. EIMS m/z: $210\left(\mathrm{M}^{+}\right)$. Anal. Calcd $\left(\mathrm{C}_{10} \mathrm{H}_{10} \mathrm{O}_{5}\right)$ : $\mathrm{C}, \mathrm{H}$.

6-(Hydroxymethyl)-2-phenyl-4,5,6,7-tetrahydro-1-benzofuran4-one (13b). A suspension of manganese(III) acetate dihydrate (3.0 $\mathrm{g}, 11.5 \mathrm{mmol})$ in glacial acetic acid $(45 \mathrm{~mL})$ was heated to $80^{\circ} \mathrm{C}$ under argon until it dissolved. The solution was cooled to $45^{\circ} \mathrm{C}$, a solution of compound $12(823 \mathrm{mg}, 5.78 \mathrm{mmol})$ and phenylacetylene $(0.76 \mathrm{~mL}, 6.94 \mathrm{mmol})$ in glacial acetic acid $(12 \mathrm{~mL})$ was added dropwise, and the mixture was stirred for $2 \mathrm{~h}$. After the mixture was cooled to room temperature, the solvent was removed under reduced pressure, and the residue was dissolved in water $(6 \mathrm{~mL})$, neutralized with $\mathrm{NaHCO}_{3}$ saturated solution, and extracted with AcOEt. The organic phase was dried $\left(\mathrm{Na}_{2} \mathrm{SO}_{4}\right)$ and concentrated to dryness. The crude product was purified by column chromatography with 1:1 AcOEt/hexane as the eluent to afford the title compound (403 $\mathrm{mg}, 30 \%)$ as a light-brown solid. mp $131-132{ }^{\circ} \mathrm{C}$ (toluene). IR: $3362,1650 .{ }^{1} \mathrm{H} \mathrm{NMR}\left(\mathrm{CDCl}_{3}, \delta\right): 2.38-2.48(\mathrm{~m}, 1 \mathrm{H}$, $\left.1 \mathrm{H}_{5}\right), 2.59-2.65\left(\mathrm{~m}, 2 \mathrm{H}, \mathrm{H}_{6}, 1 \mathrm{H}_{5}\right), 2.87(\mathrm{dd}, 1 \mathrm{H}, J=17.2,9.4 \mathrm{~Hz}$, $\left.1 \mathrm{H}_{7}\right), 3.02\left(\mathrm{dd}, 1 \mathrm{H}, J=17.3,4.8 \mathrm{~Hz}, 1 \mathrm{H}_{7}\right), 3.72-3.74(\mathrm{~m}, 2 \mathrm{H}$, $\left.-\mathrm{CH}_{2} \mathrm{OH}\right), 6.88\left(\mathrm{~s}, 1 \mathrm{H}, \mathrm{H}_{3}\right), 7.30\left(\mathrm{t}, 1 \mathrm{H}, J=7.3 \mathrm{~Hz}, \mathrm{H}_{4} \mathrm{Ph}\right), 7.40$ $\left(\mathrm{dd}, 2 \mathrm{H}, J=8.0,6.9 \mathrm{~Hz}, \mathrm{H}_{3}+\mathrm{H}_{5} \mathrm{Ph}\right), 7.65(\mathrm{~d}, 2 \mathrm{H}, J=8.0 \mathrm{~Hz}$, $\left.\mathrm{H}_{2}+\mathrm{H}_{6} \mathrm{Ph}\right)$. EIMS m/z): $242\left(\mathrm{M}^{+}\right)$. Anal. Calcd $\left(\mathrm{C}_{15} \mathrm{H}_{14} \mathrm{O}_{3}\right.$. $\left.0.15 \mathrm{H}_{2} \mathrm{O}\right): \mathrm{C}, \mathrm{H}$.

Ethyl 6-(Hydroxymethyl)-3-methyl-4-oxo-4,5,6,7-tetrahydro-1benzofuran-2-carboxylate (13c). A solution of $12(0.60 \mathrm{~g}, 4.2 \mathrm{mmol})$ and ethyl 2-chloroacetoacetate $(0.64 \mathrm{~mL}, 4.64 \mathrm{mmol})$ in $\mathrm{MeOH}$ $(2.3 \mathrm{~mL})$ was added with stirring to a mixture of $\mathrm{KOH}(0.39 \mathrm{~g}, 6.9$ $\mathrm{mmol})$ and water $(14 \mathrm{~mL})$. Stirring was continued at room temperature for $36 \mathrm{~h}$, and $\mathrm{H}_{2} \mathrm{O}(9 \mathrm{~mL})$ was added, followed by enough $10 \% \mathrm{HCl}$ to bring the mixture to $\mathrm{pH} 3$. After being stirred for $1 \mathrm{~h}$, the mixture was extracted with ether and the organic layer was washed with $5 \% \mathrm{NaHCO}_{3}$, was dried $\left(\mathrm{Na}_{2} \mathrm{SO}_{4}\right)$, and was concentrated to dryness, affording $0.26 \mathrm{~g}$ of an oil that, upon column chromatography with 1:1 AcOEt/hexane as the eluent, gave $0.16 \mathrm{~g}$ of a white solid that was identified as the ester 13c. From the basic aqueous phase, more ester 13c $(0.23 \mathrm{~g})$ crystallized and was collected by filtration in $40 \%$ yield. $\mathrm{mp} 81-83^{\circ} \mathrm{C}$. IR: 3380,1685 , 1600. ${ }^{1} \mathrm{H} \mathrm{NMR}\left(\mathrm{CDCl}_{3}, \delta\right): 1.39\left(\mathrm{t}, 3 \mathrm{H}, J=7.1 \mathrm{~Hz},-\mathrm{CH}_{2} \mathrm{CH}_{3}\right)$, $2.41-2.57\left(\mathrm{~m}, 3 \mathrm{H}, \mathrm{H}_{6}+\mathrm{H}_{5}\right), 2.55\left(\mathrm{~s}, 3 \mathrm{H},-\mathrm{CH}_{3}\right), 2.82(\mathrm{dd}, 1 \mathrm{H}, J$ $\left.=17.5,9.3 \mathrm{~Hz}, 1 \mathrm{H}_{7}\right), 3.06\left(\mathrm{dd}, 1 \mathrm{H}, J=17.9,5.3 \mathrm{~Hz}, 1 \mathrm{H}_{7}\right)$, $3.60-3.80\left(\mathrm{~m}, 2 \mathrm{H}, \mathrm{C} \mathrm{H}_{2} \mathrm{OH}\right), 4.38\left(\mathrm{q}, 2 \mathrm{H}, J=7.1 \mathrm{~Hz},-\mathrm{CH}_{2} \mathrm{CH}_{3}\right)$. EIMS $m / z: 252\left(\mathrm{M}^{+}\right)$. Anal. Calcd $\left(\mathrm{C}_{13} \mathrm{H}_{16} \mathrm{O}_{5}\right): \mathrm{C}, \mathrm{H}$.

Methyl 6-(Hydroxymethyl)-4-oxo-4,5,6,7-tetrahydro-1-benzofuran-3-carboxylate (13d). To a solution of the acid 13a $(0.50 \mathrm{~g}$, $2.38 \mathrm{mmol})$ in anhydrous methanol $(20 \mathrm{~mL})$, an excess amount of a diazomethane solution was added, followed by agitation at room temperature overnight. The solution was then concentrated to dryness to afford the title compound $(0.52 \mathrm{~g}, 97 \%)$ as a yellowish oil that crystallized upon standing. mp $104-106^{\circ} \mathrm{C}$. IR: 3392,1734 , 1684, 1549. ${ }^{1} \mathrm{H}$ NMR $\left(\mathrm{CDCl}_{3}, \delta\right): 2.36-2.60\left(\mathrm{~m}, 3 \mathrm{H}, \mathrm{H}_{5}, \mathrm{H}_{6}\right), 2.78$ $\left(\mathrm{dd}, 1 \mathrm{H}, J=17.2,8.8 \mathrm{~Hz}, 1 \mathrm{H}_{7}\right), 3.02(\mathrm{dd}, 1 \mathrm{H}, J=17.2,4.5 \mathrm{~Hz}$, $\left.1 \mathrm{H}_{7}\right), 3.59-3.76\left(\mathrm{~m}, 2 \mathrm{H}, \mathrm{CH}_{2}-\mathrm{OH}\right), 3.80\left(\mathrm{~s}, 3 \mathrm{H},-\mathrm{CH}_{3}\right), 7.86(\mathrm{~s}$, $\left.1 \mathrm{H}, \mathrm{H}_{2}\right)$. CIMS m/z: $225\left(\mathrm{MH}^{+}\right)$. Anal. Calcd $\left(\mathrm{C}_{11} \mathrm{H}_{12} \mathrm{O}_{5}\right): \mathrm{C}, \mathrm{H}$.

[3-(Methoxycarbonyl)-4-oxo-4,5,6,7-tetrahydro-1-benzofuran-6yl]methyl $p$-Toluenesulfonate (14a). $p$-Toluenesulfonyl chloride (200 mg, $1.03 \mathrm{mmol}$ ) was added to a solution of hydroxyester 13d $(180 \mathrm{mg}, 0.80 \mathrm{mmol})$ in dry pyridine $(2 \mathrm{~mL})$ at $0{ }^{\circ} \mathrm{C}$, and the mixture was stirred at this temperature for $24 \mathrm{~h}$. After the addition of water $(5 \mathrm{~mL})$ and the extraction with $\mathrm{CH}_{2} \mathrm{Cl}_{2}$, the organic layer was washed with water, was dried $\left(\mathrm{Na}_{2} \mathrm{SO}_{4}\right)$, and was concentrated to dryness, affording $315 \mathrm{mg}$ of a clear solid that was crystallized in 2-propanol to give the title compound $(136 \mathrm{mg}, 45 \%)$ as a white solid. mp $124-126^{\circ} \mathrm{C}$. IR: $1741,1678,1591,1356,1173 .{ }^{1} \mathrm{H}$ NMR $\left(\mathrm{CDCl}_{3}, \delta\right): 2.32-2.54\left(\mathrm{~m}, 2 \mathrm{H}, \mathrm{H}_{5}\right), 2.46\left(\mathrm{~s}, 3 \mathrm{H}, \mathrm{CH}_{3}-\mathrm{Ph}\right)$, $2.65-2.84\left(\mathrm{~m}, 2 \mathrm{H}, \mathrm{H}_{6}, \mathrm{H}_{7}\right), 3.05\left(\mathrm{dd}, 1 \mathrm{H}, J=16.7,4.8 \mathrm{~Hz}, 1 \mathrm{H}_{7}\right)$, $3.85\left(\mathrm{~s}, 3 \mathrm{H}, \mathrm{COOCH}_{3}\right), 3.97-4.10\left(\mathrm{~m}, 2 \mathrm{H}, \mathrm{CH}_{2} \mathrm{OH}\right), 7.36(\mathrm{~d}, 2 \mathrm{H}$, $\left.J=8.0 \mathrm{~Hz}, \mathrm{H}_{3}+\mathrm{H}_{5} \mathrm{Ts}\right), 7.78\left(\mathrm{~d}, 2 \mathrm{H}, J=7.7 \mathrm{~Hz}, \mathrm{H}_{2}+\mathrm{H}_{6} \mathrm{Ts}\right)$, $7.89\left(\mathrm{~s}, 1 \mathrm{H}, \mathrm{H}_{2}\right)$. CIMS m/z: $379\left(\mathrm{MH}^{+}\right)$. Anal. Calcd $\left(\mathrm{C}_{18} \mathrm{H}_{18} \mathrm{O}_{7^{-}}\right.$ $\left.\mathrm{S} \cdot 0.25 \mathrm{C}_{3} \mathrm{H}_{8} \mathrm{O}\right): \mathrm{C}, \mathrm{H}, \mathrm{S}$.

(4-Oxo-2-phenyl-4,5,6,7-tetrahydro-1-benzofuran-6-yl)methyl $p$ Toluenesulfonate (14b). We prepared the title compound in $63 \%$ yield by using the same procedure that was described for $\mathbf{1 4 a}$ by substituting 13d for 13b. mp 160-161 ${ }^{\circ} \mathrm{C}$ (2-propanol). IR: 1667 , 1358, 1173. ${ }^{1} \mathrm{H}$ NMR $\left(\mathrm{CDCl}_{3}, \delta\right): 2.31-2.56\left(\mathrm{~m}, 2 \mathrm{H}, \mathrm{H}_{5}\right), 2.44(\mathrm{~s}$, $\left.3 \mathrm{H},-\mathrm{CH}_{3}\right), 2.70-2.77\left(\mathrm{~m}, 1 \mathrm{H}, \mathrm{H}_{6}\right), 2.84(\mathrm{dd}, 1 \mathrm{H}, J=17.1,9.7$ $\left.\mathrm{Hz}, 1 \mathrm{H}_{7}\right), 3.00\left(\mathrm{dd}, 1 \mathrm{H}, J=16.7,4.5 \mathrm{~Hz}, 1 \mathrm{H}_{7}\right), 4.01-4.14(\mathrm{~m}$, $\left.2 \mathrm{H},-\mathrm{CH}_{2} \mathrm{OTs}\right), 6.84$ (s, $\left.1 \mathrm{H}, \mathrm{H}_{3}\right), 7.28-7.43\left(\mathrm{~m}, 5 \mathrm{H}, \mathrm{H}_{3}+\mathrm{H}_{5} \mathrm{Ts}\right.$, and $\mathrm{H}_{3}+\mathrm{H}_{4}+\mathrm{H}_{5} \mathrm{Ph}$ ), 7.62-7.65 (m, 2H, $\left.\mathrm{H}_{2}+\mathrm{H}_{6} \mathrm{Ph}\right), 7.80$ (d, $2 \mathrm{H}, J=8.2 \mathrm{~Hz}, \mathrm{H}_{2}+\mathrm{H}_{6}$ Ts). EIMS $m / z: 396\left(\mathrm{M}^{+}\right)$. Anal. Calcd $\left(\mathrm{C}_{22} \mathrm{H}_{20} \mathrm{O}_{5} \mathrm{~S} \cdot 0.25 \mathrm{H}_{2} \mathrm{O} \cdot 0.25 \mathrm{C}_{3} \mathrm{H}_{8} \mathrm{O}\right): \mathrm{C}, \mathrm{H}, \mathrm{S}$.

[2-(Ethoxycarbonyl)-3-methyl-4-oxo-4,5,6,7-tetrahydro-1-benzofuran-6-yl]methyl $\boldsymbol{p}$-Toluenesulfonate (14c). We prepared the title compound in $52 \%$ yield by using the same procedure that was described for $\mathbf{1 4 a}$ by substituting $\mathbf{1 3 d}$ for $\mathbf{1 3 c}$. mp $112-115{ }^{\circ} \mathrm{C}$ 
(2-propanol). IR: 1705, 1677, 1372, 1177. ${ }^{1} \mathrm{H}$ NMR $\left(\mathrm{CDCl}_{3}, \delta\right)$ : $1.38\left(\mathrm{t}, 3 \mathrm{H}, J=7.0 \mathrm{~Hz},-\mathrm{CH}_{2} \mathrm{CH}_{3}\right), 2.30-2.55\left(\mathrm{~m}, 2 \mathrm{H}, \mathrm{H}_{5}\right), 2.46$ $\left(\mathrm{s}, 3 \mathrm{H}, \mathrm{H}_{3} \mathrm{C}-\mathrm{Ph}\right), 2.51\left(\mathrm{~s}, 3 \mathrm{H},-\mathrm{CH}_{3}\right), 2.65-2.80\left(\mathrm{~m}, 2 \mathrm{H}, 1 \mathrm{H}_{7}+\right.$ $\left.\mathrm{H}_{6}\right), 3.02\left(\mathrm{dd}, 1 \mathrm{H}, J=16.7,3.8 \mathrm{~Hz}, 1 \mathrm{H}_{7}\right), 3.98-4.10(\mathrm{~m}, 2 \mathrm{H}$, $-\mathrm{CH}_{2}-\mathrm{OTs}$ ), $4.37\left(\mathrm{q}, 2 \mathrm{H}, J=7.1 \mathrm{~Hz},-\mathrm{CH}_{2} \mathrm{CH}_{3}\right), 7.36(\mathrm{~d}, 2 \mathrm{H}, J$ $\left.=7.9 \mathrm{~Hz}, \mathrm{H}_{3}+\mathrm{H}_{5} \mathrm{Ph}\right), 7.78\left(\mathrm{~d}, 2 \mathrm{H}, J=8.2 \mathrm{~Hz}, \mathrm{H}_{2}+\mathrm{H}_{6} \mathrm{Ph}\right)$. EIMS m/z: $361\left(\mathrm{M}^{+}\right)$. Anal. Calcd $\left(\mathrm{C}_{20} \mathrm{H}_{22} \mathrm{O}_{7} \mathrm{~S} \cdot 0.1 \mathrm{H}_{2} \mathrm{O}\right): \mathrm{C}, \mathrm{H}, \mathrm{S}$.

Methyl 6-\{[4-(4-Fluorobenzoyl)piperidin-1-yl]methyl\}-4-oxo4,5,6,7-tetrahydro-1-benzofuran-3-carboxylate (15a). A mixture of tosylate 14a (120 mg, $0.3 \mathrm{mmol}$ ) and 4-(4-fluorobenzoyl)piperidine $(132 \mathrm{mg}, 0.64 \mathrm{mmol})$ in acetonitrile $(3 \mathrm{~mL})$ was stirred under reflux for $22 \mathrm{~h}$. After cooling to room temperature, the solvent was removed under reduced pressure, and the residue was dissolved in $\mathrm{CH}_{2} \mathrm{Cl}_{2}$, was washed with water, was dried $\left(\mathrm{Na}_{2} \mathrm{SO}_{4}\right)$, and was concentrated to dryness. The crude product was purified by column chromatography with ethanol as the eluent to afford the title compound $(58 \mathrm{mg}, 45 \%)$ as a white solid. $\mathrm{mp} 155-157{ }^{\circ} \mathrm{C}(2-$ propanol). IR: $1680,1616 .{ }^{1} \mathrm{H}$ NMR $\left(\mathrm{CDCl}_{3}, \delta\right): 1.81-1.84(\mathrm{~m}$, $\left.4 \mathrm{H},-\mathrm{N}\left(\mathrm{HCH}-\mathrm{CH}_{2}\right)_{2} \mathrm{CH}-\right), 2.04-2.55\left(\mathrm{~m}, 5 \mathrm{H},-\mathrm{CH}_{2}-\mathrm{N}-\right.$ $\left.\left(\mathrm{HCH}-\mathrm{CH}_{2}\right)_{2} \mathrm{CH}-, 1 \mathrm{H}_{5}\right), 2.62-2.70\left(\mathrm{~m}, 3 \mathrm{H}, 1 \mathrm{H}_{5}, \mathrm{H}_{6}, 1 \mathrm{H}_{7}\right)$, 2.85-3.08 (m, 2H, $\left.-\mathrm{N}\left(\mathrm{HCH}-\mathrm{CH}_{2}\right)_{2} \mathrm{CH}-\right), 3.02-3.22(\mathrm{~m}, 2 \mathrm{H}$, $\left.1 \mathrm{H}_{7},-\mathrm{N}\left(\mathrm{HCH}-\mathrm{CH}_{2}\right)_{2} \mathrm{CH}-\right), 3.86\left(\mathrm{~s}, 3 \mathrm{H},-\mathrm{CH}_{3}\right), 7.10-7.16(\mathrm{~m}$, $2 \mathrm{H}, o-\mathrm{F}-\mathrm{Ph}), 7.89$ (s, 1H, $\left.\mathrm{H}_{2}\right), 7.93-7.98$ (m, 2H, $\left.m-\mathrm{F}-\mathrm{Ph}\right) . \mathrm{CIMS}$ $m / z: 414\left(\mathrm{MH}^{+}\right)$. Anal. Calcd $\left(\mathrm{C}_{23} \mathrm{H}_{24} \mathrm{FNO}_{5}\right): \mathrm{C}, \mathrm{H}, \mathrm{N}$.

6-\{[4-(4-Fluorobenzoyl)piperidin-1-yl]methyl\}-2-phenyl-4,5,6,7tetrahydro-1-benzofuran-4-one $(\mathbf{1 5 b})$. We prepared the title compound by using the same procedure that was described for $\mathbf{1 5} \mathbf{a}$ by substituting 14a for 14b. Purification by column chromatography with 1:2 AcOEt/hexane as the eluent afforded the title compound (37\%) as a white solid. mp $181-182{ }^{\circ} \mathrm{C}$ (2-propanol). IR: 1741 , $1668,1517 .{ }^{1} \mathrm{H}$ NMR $\left(\mathrm{CDCl}_{3}, \delta\right): 1.84-2.04(\mathrm{~m}, 4 \mathrm{H},-\mathrm{N}-$ $\left.\left(\mathrm{HCH}-\mathrm{CH}_{2}\right)_{2} \mathrm{CH}-\right), 2.29-2.50\left(\mathrm{~m}, 5 \mathrm{H}, 1 \mathrm{H}_{5}\right.$ and $-\mathrm{CH}_{2}-\mathrm{N}-$ $\left.\left(\mathrm{HCH}-\mathrm{CH}_{2}\right)_{2} \mathrm{CH}-\right), 2.63-2.76\left(\mathrm{~m}, 3 \mathrm{H}, 1 \mathrm{H}_{7}+\mathrm{H}_{6}+1 \mathrm{H}_{5}\right)$, 2.85-2.88 (m, 2H, $\left.-\mathrm{N}\left(\mathrm{HCH}-\mathrm{CH}_{2}\right)_{2} \mathrm{CH}-\right), 3.04-3.20(\mathrm{~m}, 2 \mathrm{H}$, $\left.1 \mathrm{H}_{7},-\mathrm{N}\left(\mathrm{HCH}-\mathrm{CH}_{2}\right)_{2} \mathrm{CH}-\right), 6.87\left(\mathrm{~s}, 1 \mathrm{H}, \mathrm{H}_{3}\right), 7.11-7.16(\mathrm{~m}, 2 \mathrm{H}$, $o-\mathrm{F}-\mathrm{Ph}), 7.30-7.33\left(\mathrm{~m}, 1 \mathrm{H}, \mathrm{H}_{4} \mathrm{Ph}\right), 7.39(\mathrm{dd}, 2 \mathrm{H}, J=16.0,8.2$ $\left.\mathrm{Hz}, \mathrm{H}_{3} \mathrm{Ph}\right), 7.65\left(\mathrm{~d}, 2 \mathrm{H}, J=6.5 \mathrm{~Hz}, \mathrm{H}_{2} \mathrm{Ph}\right), 7.94-7.99(\mathrm{~m}, 2 \mathrm{H}$, $m$-F-Ph). EIMS m/z: $431\left(\mathrm{M}^{+}\right)$. Anal. Calcd $\left(\mathrm{C}_{27} \mathrm{H}_{26} \mathrm{FNO}_{3} \cdot{ }_{3} /{ }_{4} \mathrm{H}_{2} \mathrm{O}\right)$ : C, H, N.

Ethyl 6-\{[4-(4-Fluorobenzoyl)piperidin-1-yl]methyl\}-3-methyl4-oxo-4,5,6,7-tetrahydro-1-benzofuran-2-carboxylate (15c). We prepared the title compound by using the same procedure that was described for 15a by substituting 14a for 14c. Purification by column chromatography with 1:2 AcOEt/hexane as the eluent afforded the title compound (25\%) as a white solid. mp 130-132 ${ }^{\circ} \mathrm{C}$. IR: $1715,1694,1673 .{ }^{1} \mathrm{H}$ NMR $\left(\mathrm{CDCl}_{3}, \delta\right): 1.38(\mathrm{t}, 3 \mathrm{H}, J=$ $\left.7.11 \mathrm{~Hz},-\mathrm{CH}_{2} \mathrm{CH}_{3}\right), 1.80-1.84\left(\mathrm{~m}, 4 \mathrm{H},-\mathrm{N}\left(\mathrm{HCH}-\mathrm{CH}_{2}\right)_{2} \mathrm{CH}-\right)$, 2.04-2.39 (m, 6H, $\left.\mathrm{H}_{5},-\mathrm{CH}_{2}-\mathrm{N}\left(\mathrm{HCH}-\mathrm{CH}_{2}\right)_{2} \mathrm{CH}-\right), 2.54(\mathrm{~s}, 3 \mathrm{H}$, $\left.-\mathrm{CH}_{3}\right), 2.61-2.71\left(\mathrm{~m}, 2 \mathrm{H}, \mathrm{H}_{6}+1 \mathrm{H}_{7}\right), 2.85-2.90(\mathrm{~m}, 2 \mathrm{H}$, $\left.-\mathrm{N}\left(\mathrm{HCH}-\mathrm{CH}_{2}\right)_{2} \mathrm{CH}-\right)$, 3.06-3.08 (m, 2H, $1 \mathrm{H}_{7}+-\mathrm{N}(\mathrm{HCH}-$ $\left.\mathrm{CH}_{2}\right)_{2} \mathrm{CH}-$ ), 4.37 (q, $\left.2 \mathrm{H}, J=7.0 \mathrm{~Hz},-\mathrm{CH}_{2} \mathrm{CH}_{3}\right), 7.13(\mathrm{t}, 2 \mathrm{H}, J$ $=6.5 \mathrm{~Hz}, o-\mathrm{F}-\mathrm{Ph}), 7.93-7.98(\mathrm{~m}, 2 \mathrm{H}, \mathrm{m}-\mathrm{F}-\mathrm{Ph})$. IEMS $m / z: 441$ $\left(\mathrm{M}^{+}\right)$. Anal. Calcd: $\left(\mathrm{C}_{25} \mathrm{H}_{28} \mathrm{FNO}_{5} \cdot 0.25 \mathrm{C}_{3} \mathrm{H}_{8} \mathrm{O}\right): \mathrm{C}, \mathrm{H}, \mathrm{N}$.

Methyl 6-\{[4-(6-Fluorobenzisoxazol-3-yl)piperidin-1-yl]methyl\}4-oxo-4,5,6,7-tetrahydro-1-benzofuran-3-carboxylate (16a). A solution of tosylate $\mathbf{1 4 a}(95 \mathrm{mg}, 0.25 \mathrm{mmol})$ and 4-(6-fluorobenzisoxazol3-yl)piperidine (108 $\mathrm{mg}, 0.49 \mathrm{mmol}$ ) was refluxed in acetonitrile ( $3 \mathrm{~mL}$ ) for $24 \mathrm{~h}$. The precipitate was filtered off, the solvent was removed in vacuo, and the residue was dissolved in $\mathrm{CH}_{2} \mathrm{Cl}_{2}$. This solution was washed twice with water and was dried $\left(\mathrm{Na}_{2} \mathrm{SO}_{4}\right)$, and the solvent was removed in vacuo, affording $149 \mathrm{mg}$ of a brown solid that, upon column chromatography with 2:1 AcOEt/hexane as the eluent, gave the title compound $(86 \mathrm{mg}, 80 \%)$ as a lightbrown crystalline solid. mp $140-142{ }^{\circ} \mathrm{C}$ (2-propanol). IR: 1744 , 1683, 1614, 1546. ${ }^{1} \mathrm{H}$ NMR $\left(\mathrm{CDCl}_{3}, \delta\right): 2.04-2.44\left(\mathrm{~m}, 9 \mathrm{H}, 1 \mathrm{H}_{5}\right.$, $\left.-\mathrm{CH}_{2}-\mathrm{N}\left(\mathrm{HCH}-\mathrm{CH}_{2}\right)_{2} \mathrm{CH}-\right), 2.64-2.75\left(\mathrm{~m}, 3 \mathrm{H}, 1 \mathrm{H}_{5}, \mathrm{H}_{6}, 1 \mathrm{H}_{7}\right)$, 2.92-3.05 (m, 4H, $\left.1 \mathrm{H}_{7},-\mathrm{N}\left(\mathrm{HCH}-\mathrm{CH}_{2}\right)_{2} \mathrm{CH}-\right), 3.86(\mathrm{~s}, 3 \mathrm{H}$, $\left.-\mathrm{CH}_{3}\right), 7.06\left(\mathrm{dt}, 1 \mathrm{H}, J=8.8,2.1 \mathrm{~Hz}, \mathrm{H}_{5}\right.$ benzisox), 7.22-7.23 (m, $1 \mathrm{H}, \mathrm{H}_{7}$ benzisox), 7.68 (dd, $1 \mathrm{H}, J=8.7,5.1 \mathrm{~Hz}, \mathrm{H}_{4}$ benzisox), $7.90\left(\mathrm{~s}, 1 \mathrm{H}, \mathrm{H}_{2}\right)$. EIMS $m / z: 426\left(\mathrm{M}^{+}\right)$. Anal. Calcd $\left(\mathrm{C}_{23} \mathrm{H}_{23} \mathrm{FN}_{2} \mathrm{O}_{5} \cdot 1 /\right.$ $\left.{ }_{6} \mathrm{H}_{2} \mathrm{O}\right): \mathrm{C}, \mathrm{H}, \mathrm{N}$.
6-\{[4-(6-Fluorobenzisoxazol-3-yl)piperidin-1-yl]methyl\}-2-phenyl-4,5,6,7-dihydro-1-benzofuran-4-one (16b). We prepared the title compound by using the same procedure that was described for $\mathbf{1 6 a}$ by substituting $\mathbf{1 4 a}$ for $\mathbf{1 4 b}$. Purification by column chromatography with 1:2 AcOEt/hexane as the eluent afforded the title compound $(30 \%)$ as a light-brown solid. mp $162-164{ }^{\circ} \mathrm{C}$. IR: 2931, 1673, 1611, 1440, 1119. ${ }^{1} \mathrm{H}$ NMR $\left(\mathrm{CDCl}_{3}, \delta\right): 2.06-2.49(\mathrm{~m}, 9 \mathrm{H}$, $\left.-\mathrm{CH}_{2}-\mathrm{N}\left(\mathrm{HCH}-\mathrm{CH}_{2}\right)_{2} \mathrm{CH}-, 1 \mathrm{H}_{5}\right), 2.67-2.78\left(\mathrm{~m}, 3 \mathrm{H}, 1 \mathrm{H}_{5}, \mathrm{H}_{6}\right.$, $\left.1 \mathrm{H}_{7}\right), 2.96-3.20\left(\mathrm{~m}, 4 \mathrm{H},-\mathrm{N}\left(\mathrm{HCH}-\mathrm{CH}_{2}\right)_{2} \mathrm{CH}-+1 \mathrm{H}_{7}\right), 6.88(\mathrm{~s}$, $1 \mathrm{H}, \mathrm{H}_{3}$ ), 7.06 (dt, $1 \mathrm{H}, J=8.8,2.1 \mathrm{~Hz}, \mathrm{H}_{5}$ benzisox), 7.22-7.37 $\left(\mathrm{m}, 2 \mathrm{H}, \mathrm{H}_{7}\right.$ benzisox, and $\left.\mathrm{H}_{4} \mathrm{Ph}\right), 7.41(\mathrm{dd}, 2 \mathrm{H}, J=6.9,1.4 \mathrm{~Hz}$, $\mathrm{H}_{3}+\mathrm{H}_{5} \mathrm{Ph}$ ), 7.64-7.72 (m, 3H, $\mathrm{H}_{4}$ benzisox, and $\mathrm{H}_{2}+\mathrm{H}_{6} \mathrm{Ph}$ ). CIMS m/z: $445\left(\mathrm{MH}^{+}\right)$. Hydrochloride: Anal. Calcd $\left(\mathrm{C}_{27} \mathrm{H}_{25} \mathrm{FN}_{2} \mathrm{O}_{3} \cdot \mathrm{H}-\right.$ $\left.\mathrm{Cl} \cdot 0.8 \mathrm{H}_{2} \mathrm{O}\right): \mathrm{C}, \mathrm{H}, \mathrm{N}$.

Ethyl 6-\{[4-(6-Fluorobenzisoxazol-3-yl)piperidin-1-yl]methyl\}3-methyl-4-oxo-4,5,6,7-tetrahydro-1-benzofuran-2-carboxylate (16c). We prepared the title compound by using the same procedure that was described for $\mathbf{1 6 a}$ by substituting $\mathbf{1 4 a}$ for $\mathbf{1 4 c}$. Purification by column chromatography with 1:4 AcOEt/hexane as the eluent afforded the title compound (84\%) as a colorless oil. IR: 3524, $1711,1680,1612,1553 .{ }^{1} \mathrm{H} \mathrm{NMR}\left(\mathrm{CDCl}_{3}, \delta\right): 1.39(\mathrm{t}, 3 \mathrm{H}, J=7.1$ $\left.\mathrm{Hz},-\mathrm{CH}_{2} \mathrm{CH}_{3}\right), 2.04-2.18\left(\mathrm{~m}, 4 \mathrm{H},-\mathrm{N}\left(\mathrm{HCH}-\mathrm{CH}_{2}\right)_{2} \mathrm{CH}-\right)$, $2.28-2.36\left(\mathrm{~m}, 4 \mathrm{H},-\mathrm{CH}_{2}-\mathrm{N}\left(\mathrm{HCH}-\mathrm{CH}_{2}\right)_{2} \mathrm{CH}-\right), 2.49-2.55(\mathrm{~m}$, $\left.2 \mathrm{H}, \mathrm{H}_{5}\right), 2.55\left(\mathrm{~s}, 3 \mathrm{H},-\mathrm{CH}_{3}\right), 2.65-2.78\left(\mathrm{~m}, 2 \mathrm{H}, \mathrm{H}_{6}+1 \mathrm{H}_{7}\right)$, $3.02-3.20\left(\mathrm{~m}, 4 \mathrm{H},-\mathrm{N}\left(\mathrm{HCH}-\mathrm{CH}_{2}\right)_{2} \mathrm{CH}-+1 \mathrm{H}_{7}\right), 4.38(\mathrm{q}, 2 \mathrm{H}, J$ $\left.=7.0 \mathrm{~Hz},-\mathrm{CH}_{2} \mathrm{CH}_{3}\right), 7.08\left(\mathrm{dt}, 1 \mathrm{H}, J=8.8,2.1 \mathrm{~Hz}, \mathrm{H}_{5}\right.$ benzisox), $7.23-7.26\left(\mathrm{~m}, 1 \mathrm{H}, \mathrm{H}_{7}\right.$ benzisox), $7.71(\mathrm{dd}, 1 \mathrm{H}, J=8.4,5.1 \mathrm{~Hz}$, $\mathrm{H}_{4}$ benzisox). IEMS $\mathrm{m} / z$ : $454\left(\mathrm{M}^{+}\right)$. Hydrochloride: $\mathrm{mp}$ 245-247 ${ }^{\circ} \mathrm{C}$. Anal. Calcd $\left(\mathrm{C}_{25} \mathrm{H}_{27} \mathrm{FN}_{2} \mathrm{O}_{5} \cdot \mathrm{HCl} \cdot{ }^{2} /{ }_{3} \mathrm{H}_{2} \mathrm{O}\right): \mathrm{C}, \mathrm{H}, \mathrm{N}$.

6-\{[4-(4-Fluorobenzoyl)piperazin-1-yl]methyl\}-4,5,6,7-tetrahydro1-benzofuran-4-one (18). A solution of piperazine $\mathbf{1 7}^{30}(96 \mathrm{mg}$, $0.41 \mathrm{mmol}), 1$-hydroxy benzotriazole (HOBt) $(55 \mathrm{mg}, 0.41 \mathrm{mmol}$ ), and 4-fluorobenzoic acid (57 mg, $0.41 \mathrm{mmol}$ ) in anhydrous $\mathrm{CH}_{2} \mathrm{Cl}_{2}$ $(5 \mathrm{~mL})$ was stirred under argon at room temperature for $15 \mathrm{~min}$ and was then cooled to $0{ }^{\circ} \mathrm{C}$. At this temperature, dicyclohexylcarbodiimide (DCC) ( $84 \mathrm{mg}, 0.41 \mathrm{mmol}$ ) was added, and the reaction mixture was kept at $0-5{ }^{\circ} \mathrm{C}$ for $1 \mathrm{~h}$, was then allowed to reach room temperature, and was left for $48 \mathrm{~h}$. The precipitated dicyclohexylurea was filtered off, and the filtrate was washed several times with $5 \% \mathrm{NaHCO}_{3}$ and water, was dried $\left(\mathrm{Na}_{2} \mathrm{SO}_{4}\right)$, and was condensed to dryness. We purified the oily residue by flash chromatography by using 1:4 AcOEt/hexane as the eluent to give the title compound $(65 \mathrm{mg}, 45 \%)$ as a white crystalline solid. $\mathrm{mp}$ 129-130 ${ }^{\circ} \mathrm{C}$ (2-propanol). IR: 2927, 1677, 1628, 1433. ${ }^{1} \mathrm{H}$ NMR $\left(\mathrm{CDCl}_{3}, \delta\right): 2.28\left(\mathrm{dd}, 1 \mathrm{H}, J=16.0,10.1 \mathrm{~Hz}, \mathrm{H}_{5}\right), 2.35-2.69(\mathrm{~m}$, $9 \mathrm{H}, 1 \mathrm{H}_{5}, \mathrm{H}_{6}, 1 \mathrm{H}_{7},-\mathrm{CH}_{2}-\mathrm{N}\left(\mathrm{CH}_{2}-\mathrm{CH}_{2}\right)_{2} \mathrm{~N}$, ), 3.07 (dd, $1 \mathrm{H}, J=$ 16.0, 3.6 Hz, $\left.\mathrm{H}_{7}\right), 3.36-3.65\left(\mathrm{~m}, 4 \mathrm{H}, \mathrm{N}\left(\mathrm{CH}_{2}-\mathrm{CH}_{2}\right)_{2} \mathrm{NCO}\right), 6.66$ (d, $\left.1 \mathrm{H}, J=2.0 \mathrm{~Hz}, \mathrm{H}_{3}\right), 7.08$ (t, $2 \mathrm{H}, J=8.6 \mathrm{~Hz}, \mathrm{H}_{3}+\mathrm{H}_{5} \mathrm{Ph}$ ), 7.33 $\left(\mathrm{d}, 1 \mathrm{H}, J=2.0 \mathrm{~Hz}, \mathrm{H}_{2}\right), 7.32\left(\mathrm{dd}, 2 \mathrm{H}, J=8.7,5.4 \mathrm{~Hz}, \mathrm{H}_{2}+\mathrm{H}_{6}\right.$ $\mathrm{Ph})$.EIMS $m / z: 356\left(\mathrm{M}^{+}\right)$. Hydrochloride: Anal. Calcd $\left(\mathrm{C}_{20} \mathrm{H}_{21} \mathrm{FN}_{2} \mathrm{O}_{3} \cdot \mathrm{HCl} \cdot 2 /\right.$ $\left.3 \mathrm{H}_{2} \mathrm{O}\right): \mathrm{C}, \mathrm{H}, \mathrm{N}$.

Pharmacology. The affinities of the new compounds for cloned human $\mathrm{D}_{2}, 5-\mathrm{HT}_{2 \mathrm{~A}}$, and $5-\mathrm{HT}_{2 \mathrm{C}}$ receptors were evaluated by in vitro binding assays that used the radioligands $\left[{ }^{3} \mathrm{H}\right]$ spiperone, $\left[{ }^{3} \mathrm{H}\right]$ ketanserin, and $\left[{ }^{3} \mathrm{H}\right]$ mesulergine, respectively, according to previously described procedures. ${ }^{28} K_{\mathrm{i}}$ values expressed as $\mathrm{p} K_{\mathrm{i}}$ were calculated according to the Cheng-Prusoff equation. ${ }^{45}$

Residue Numbering. For residues belonging to helix regions of the G-protein-coupled receptors (GPCRs), the generalized numbering scheme that was proposed by Ballesteros and Weinstein ${ }^{46}$ was used.

GPCR Modeling. The human sequences of the $5-\mathrm{HT}_{2 \mathrm{~A}}$ and $\mathrm{D}_{2}$ receptors were retrieved from the Swiss-Prot database ${ }^{47}$ and were aligned with the crystal structure of the human $\beta 2$ adrenergic G-protein-coupled receptor (PDB entry $2 \mathrm{RH} 1)^{48,49}$ by the use of ClustalX software ${ }^{50,51}$ that used the PAM250 matrix and penalties of 10 and 0.05 , respectively, for gap opening and gap elongation. The alignment was then manually refined to ensure a perfect alignment of the highly conserved residues of the GPCR superfamily according to Baldwin et al. ${ }^{52}$ The conserved disulfide bond between residue $\mathrm{C} 3.25$ at the beginning of TM3 and the cysteine 
in the middle of extracellular loop 2 (a feature common to many GPCR receptors) was also created and was kept as a constraint in the geometric optimization.

We then built 3D models by using the MODELER suite of programs, ${ }^{53}$ which yielded 15 candidate models for each receptor final structure. The best structures were selected and were optimized with the molecular modeling program MOE (molecular operating environment; Chemical Computing Group), which applied the Amber99 force field. ${ }^{54}$ PROCHECK software ${ }^{55}$ was used to assess the stereochemical quality of the minimized structures, and this resulted in good-quality parameters with an excellent distribution of $\psi$ and $\varphi$ angles in the Ramachandran plot; more than $90 \%$ of the residues were in the most favored regions. Furthermore, the resulting models must reproduce the correct orientation of the side chains for the amino acids that are strongly conserved in the GPCR superfamily, ${ }^{56-59}$ in particular, F6.51, F6.52, and W6.48, which some authors ${ }^{60}$ have implicated in the activation process. In the data that were recently published for $2 \mathrm{RH} 1,{ }^{48,49}$ the cocrystallized partial inverse agonist carazolol interacts with F6.51 and F6.52, which form an extended aromatic network that surrounds W6.48. As a result, W6.48 adopts the rotamer that is associated with the inactive state. On the basis of these findings, the conformation of these residues in the present study was set to the inactive state, which is probably more appropriate for modeling the docking of antagonists and more consistent with the inactive state of the main template structure (2RH1).

Docking Simulation. We analyzed the binding modes of the compounds in this study for the $5-\mathrm{HT}_{2 \mathrm{~A}}$ and $\mathrm{D}_{2}$ receptors by using docking simulations in the GOLD3.1.1 program. ${ }^{61}$ We docked the ligands in the active site of $5-\mathrm{HT}_{2 \mathrm{~A}} / \mathrm{D}_{2}$ by defining a region of 15 $\AA$ that was centered on the $\mathrm{CG}$ of $\mathrm{D} 3.32$, a residue that is conserved in all aminergic receptors and is known to be important in the interaction with the ligand. ${ }^{62,63}$ The best docking solution, according to the scoring function of GOLD and mutagenesis data, was subjected to energy minimization by the use of MOE. The complex was further refined in a molecular dynamics simulation that lasted 200 ps (force field MMF94x, $300 \mathrm{~K}$, time step of $2 \mathrm{fs}$ ); subsequently, the energy was minimized by the application of gradient minimization until the rms gradient was lower than $0.001 \mathrm{kcal} /$ $\mathrm{mol} \cdot \AA$.

Acknowledgment. This work was supported by grants from the CICYT (Spain, SAF2005-08025-C03) and from the Xunta de Galicia (Spain, PIDIT06PXIB203173PR). K.V. and J.S. were supported, respectively, by a predoctoral fellowship from the Diputación de A Coruña and by grants from the Instituto de Salud Carlos III (Red HERACLES RD06/0009 and COMBIOMED). J.B. received financial support from the Programa Isabel Barreto (Xunta de Galicia, Spain).

Supporting Information Available: Elemental analysis data of the new compounds. This material is available free of charge via the Internet at http://pubs.acs.org.

\section{References}

(1) WHO Fact Sheet Number 265; The World Health Organization: Geneva, Switzerland, 2001.

(2) Altar, C. A.; Martin, A. R.; Thurkauf, A. Antipsychotic Agents. In Burger's Medicinal Chemistry and Drug Discovery, 6th ed.; Abraham, D. J., Ed.; Wiley: Hoboken, NJ, 2003; Vol. 6, pp 599-672.

(3) Seeman, P.; Chou-Wong, M.; Tadesco, J.; Wong, K. Antipsychotic drug doses and neuroleptic/dopamine receptors. Nature 1976, 261, $717-719$.

(4) Hartman, D. S.; Civelli, O. Dopamine receptor diversity: molecular and pharmacological perspectives. Prog. Drug Res. 1997, 48, 173194.

(5) Seeman, P. Targeting the dopamine D2 receptor in schizophrenia. Expert Opin. Ther. Targets 2006, 10, 515-531.

(6) Sanberg, P. R. Haloperidol-induced catalepsy is mediated by postsynaptic dopamine receptors. Nature 1980, 284, 472-473.

(7) Casey, D. E. Pathophysiology of antipsychotic drug-induced movement disorders. J. Clin. Psychiatry 2004, 9, 25-28.
(8) Filton, A.; Heel, R. C. Clozapine. A review of its pharmacological properties and therapeutic use in schizophrenia. Drugs 1990, 40, 722747.

(9) Schwarz, J. T.; Brotman, A. W. A clinical guide to antipsychotic drugs. Drugs 1992, 44, 981-992.

(10) Marino, M. J.; Knutsen, L. J. S.; Williams, M. Emerging opportunities for antipsychotic drug discovery in the postgenomic era. J. Med. Chem. 2008, 51, 1077-1107.

(11) Roth, B. L.; Sheffler, D. J.; Kroeze, W. K. Magic shotguns versus magic bullets: selectively non-selective drugs for mood disorders and schizophrenia. Nat. Rev. Drug Discov. 2004, 3, 353-359.

(12) Richelson, E.; Souder, T. Binding of antipsychotic drugs to human brain receptors focus on newer generation compounds. Life Sci. 2000, $68,29-39$.

(13) Meltzer, H. Y.; Matsubara, S.; Lee, J. C. The ratios of serotonin-2 and dopamine-2 affinities differentiate atypical and typical antipsychotic drugs. Psychopharmacol. Bull. 1989, 25, 390-392.

(14) Roth, B. L.; Tandra, S.; Burgess, L. H.; Sibley, D. R.; Meltzer, H. Y. D4 receptor binding affinity does not distinguish between typical and atypical antipsychotic drugs. Psychopharmacology 1995, 120, 365368.

(15) Roth, B. L.; Meltzer, H. Y.; Khan, N. Binding of typical and atypical antipsychotic drugs to multiple neurotransmitter receptors. Adv. Pharmacol. 1998, 42, 482-485.

(16) Lowe, J. A. Atypical antipsychotics based on the D2/5-HT2 ratio hypothesis. Curr. Med. Chem. 1994, 1, 50-60.

(17) Van Oekelen, D.; Luyten, W. H. M. L.; Leysen, J. E. 5-HT2A and 5-HT2C receptors and their atypical regulation properties. Life Sci. 2003, 72, 2429-2449.

(18) Sipes, T. E.; Geyer, M. A. DOI disrupts prepulse inhibition of startle in rats via 5-HT2A receptors in the ventral pallidum. Brain Res. 1997, 761,97-104.

(19) Okuyama, S.; Chaki, S.; Kawashima, N.; Suzuki, Y.; Ogawa, S.; Kumagai, T.; Nakazato, A.; Nagamine, M.; Yamaguchi, K.; Tomisawa, $\mathrm{K}$. The atypical antipsychotic profile of NRA0045, a novel dopamine D4 and 5-hydroxytryptamine2A receptor antagonist, in rats. Br. J. Pharmacol. 1997, 121, 515-525.

(20) Payne, A. A superior antipsychotic: rational design or irrational dream. Drugs Future 2006, 31, 16.

(21) Reavill, C.; Kettle, A.; Holland, V.; Riley, G.; Blackburn, T. P. Attenuation of haloperidol-induced catalepsy by a 5-HT2C receptor antagonist. Br. J. Pharmacol. 1999, 126, 572-574.

(22) Wood, M. D.; Heidbreder, C.; Reavill, C.; Ashby, C. R., Jr.; Middlemiss, D. N. 5-HT2C receptor antagonists: potential in schizophrenia. Drug Dev. Res. 2001, 54, 88-94.

(23) Richtand, N. M.; Welge, J. A.; Logue, A. D.; Keck, P. E., Jr.; Strakowski, S. M.; McNamara, R. K. Dopamine and serotonin receptor binding and antipsychotic efficacy. Neuropsychopharmacology 2007, 32, 1715-1726.

(24) Lieberman, J. A.; Hohn, C. A.; Mikane, J.; Rai, K.; Pisciotta, A. V.; Salz, B. L.; Howard, A. Clozapine-induced agranulocytosis: noncrossreactivity with other antipsychotic drugs. J. Clin. Psychiatry 1988, 49, 271-277.

(25) Cortizo, L.; Santana, L.; Raviña, E.; Orallo, F.; Fontenla, J. A.; Castro, E.; de Ceballos, M. Synthesis and antidopaminergic activity of some 3-(aminomethyl)tetralones as analogs of butyrophenone. J. Med. Chem. 1991, 34, 2242-2247.

(26) Fontenla, J. A.; Osuna, J. A.; Rosa, E.; Castro, M. E.; Loza-García, I.; G-Ferreiro, T.; Calleja, J. M.; Sanz, F.; Rodríguez, J.; Fueyo, J.; Raviña, E.; F-Masaguer, C.; Vidal, A.; de Ceballos, M. L. Synthesis and atypical antipsychotic profile of some 2-(2-piperidinoethyl)benzocycloalkanones as analogues of butyrophenone. J. Med. Chem. 1994, 37, 2564-2573.

(27) Raviña, E.; Masaguer, C. F. Conformationally constrained butyrophenones. Synthesis and evaluation as antipsychotics. Curr. Med. Chem.: Cent. Nerv. Syst. Agents 2001, 1, 43-62.

(28) Brea, J.; Rodrigo, J.; Carrieri, A.; Sanz, F.; Cadavid, M. I.; Enguix, M. J.; Villazón, M.; Mengod, G.; Caro, Y.; Masaguer, C. F.; Raviña, E.; Centeno, N. B.; Carotti, A.; Loza, M. I. New serotonin 5-HT2A, 5-HT2B, and 5-HT2C receptor antagonists: synthesis, pharmacology, 3D-QSAR, and molecular modeling of (aminoalkyl)benzo and heterocycloalkanones. J. Med. Chem. 2002, 45, 54-71.

(29) Brea, J.; Masaguer, C. F.; Villazón, M.; Cadavid, M. I.; Raviña, E.; Fontaine, F.; Dezi, C.; Pastor, M.; Sanz, F.; Loza, M. I. Conformationally constrained butyrophenones as new pharmacological tools to study 5-HT2A and 5-HT2C receptor behaviors. Eur. J. Med. Chem. 2003, 38, 433-440.

(30) Raviña, E.; Casariego, I.; Masaguer, C. F.; Fontenla, J. A.; Montenegro, G. Y.; Rivas, M. E.; Loza, M. I.; Enguix, M. J.; Villazon, M.; Cadavid, M. I.; Demontis, G. C. Conformationally constrained butyrophenones with affinity for dopamine (D1, D2, D4) and serotonin (5-HT2A, 5-HT2B, 5-HT2C) receptors. Synthesis of aminomethylbenzo[b]fura- 
nones, and their evalution as antipsychotics. J. Med. Chem. 2000, 43 , 4678-4693.

(31) Schelkun, R. M.; Yuen, P.-W.; Wustrow, D. J.; Kinsora, J.; Su, T.Z.; Vartanian, M. G. Heteroaromatic side-chain analogs of pregabalin. Bioorg. Med. Chem. Lett. 2006, 16, 23292332.

(32) Pita, B.; Masaguer, C. F.; Raviña, E. A simple, efficient method for regioselective synthesis of 7-aminomethyl-7,8-dihydro-6H-quinolin5-ones, new potential CNS agents. Tetrahedron Lett. 2000, 41, 9829 9833.

(33) Yilmaz, M.; Pekel, A. T. Synthesis of benzofuran derivatives using manganese(III) acetate mediated addition of $\beta$-dicarbonyl compounds to alkyne and alkenes: a comparative study. Synth. Commun. 2001 , 31, 3871-3876.

(34) Alagoz, O.; Yilmaz, M.; Pekel, A. T. Free radical cyclization of 1,3dicarbonyl compounds mediated by manganese(III) acetate with alkynes and synthesis of tetrahydrobenzofurans, naphthalene, and trifluoroacetyl substituted aromatic compounds. Synth. Commun. 2006, 36, 1005-1013.

(35) Stetter, H.; Lauterbach, R. Synthesis of evodone and menthofuran. Chem. Ber. 1960, 93, 603-607.

(36) Dezi, C.; Brea, J.; Alvarado, M.; Raviña, E.; Masaguer, C. F.; Loza M. I.; Sanz, F.; Pastor, M. Multistructure 3D-QSAR studies on a series of conformationally constrained butyrophenones docked into a new homology model of the 5-HT2A receptor. J. Med. Chem. 2007, 50, 3242-3255.

(37) Nielsen, B. B.; Pickering, D. S.; Greenwood, J. R.; Brehm, L.; Gajhede M.; Schousboe, A.; Kastrup, J. S. Exploring the GluR2 ligand-binding core in complex with the bicyclical AMPA analogue (S)-4-AHCP. FEBS J. 2005, 272, 1639-1648.

(38) Hogner, A.; Kastrup, J. S.; Jin, R.; Liljefors, T.; Mayer, M. L.; Egebjerg, J.; Larsen, I. K.; Gouaux, E. Structural basis for AMPA receptor activation and ligand selectivity: crystal structures of five agonist complexes with the GluR2 ligand-binding core. J. Mol. Biol. 2002, 322, 93-109.

(39) Brough, P. A.; Aherne, W.; Barril, X.; Borgognoni, J.; Boxall, K.; Cansfield, J. E.; Cheung, K. J.; Collins, I.; Davies, N. G. M.; Drysdale, M. J.; Dymock, B.; Eccles, S. A.; Finch, H.; Fink, A.; Hayes, A.; Howes, R.; Hubbard, R. E.; James, K.; Jordan, A. M.; Lockie, A.; Martins, V.; Massey, A.; Matthews, T. P.; McDonald, E.; Northfield, C. J.; Pearl, L. H.; Prodromou, C.; Ray, S.; Raynaud, F. I.; Roughley, S. D.; Sharp, S. Y.; Surgenor, A.; Walmsley, D. L.; Webb, P.; Wood, M.; Workman, P.; Wright, L. 4,5-Diarylisoxazole Hsp90 chaperone inhibitors: potential therapeutic agents for the treatment of cancer. J. Med. Chem. 2008, 51, 196-218.

(40) Selent, J.; López, L.; Sanz, F.; Pastor, M. Multi-receptor binding profile of clozapine and olanzapine: a structural study based on the new $\beta 2$ adrenergic receptor template. ChemMedChem 2008, 3, 1194-1198.

(41) Raviña, E.; Negreira, J.; Cid, J.; Masaguer, C. F.; Rosa, E.; Rivas, M. E.; Fontenla, J. A.; Loza, M. I.; Tristan, H.; Cadavid, M. I.; Sanz, F.; Lozoya, E.; Carotti, A.; Carrieri, A. Conformationally constrained butyrophenones with mixed dopaminergic (D2) and serotoninergic (5HT2A, 5-HT2C) affinities: synthesis, pharmacology, 3D-QSAR, and molecular modeling of (aminoalkyl)benzo- and -thienocycloalkanones as putative atypical antipsychotics. J. Med. Chem. 1999, 42, 2774 2797.

(42) Duncan, R. L., Jr.; Helsley, G. C.; Welstead, W. J., Jr.; Da Vanzo, J. P.; Funderburk, W. H.; Lunsford, C. D. Aroylpiperidines and pyrrolidines. New class of potent central nervous system depressants. J. Med. Chem. 1970, 13, 1-6.

(43) Ismaiel, A. M.; Arruda, K.; Teitler, M.; Glennon, R. A. Ketanserin analogues: the effect of structural modification on 5-HT2 serotonin receptor binding. J. Med. Chem. 1995, 38, 1196-1202.

(44) Vogel, A. I. Vogel's Textbook of Practical Organic Chemistry, 5th ed.; Longman: Harlow, U.K., 1989.

(45) Cheng, Y.; Prusoff, W. H. Relation between the inhibition constant (K1) and the concentration of inhibitor which causes fifty per cent inhibition (I50) of an enzymic reaction. Biochem. Pharmacol. 1973 22, 3099-3108.
(46) Ballesteros, J.; Weinstein, H. Integrated methods for the construction of three dimensional models and computational probing of structurefunction relations in G-protein coupled receptors. Methods Neurosci. 1995, 25, 366428

(47) Boeckmann, B.; Bairoch, A.; Apweiler, R.; Blatter, M. C.; Estreicher, A.; Gasteiger, E.; Martin, M. J.; Michoud, K.; O’Donovan, C.; Phan, I.; Pilbout, S.; Schneider, M. The SWISS-PROT protein knowledgebase and its supplement TrEMBL in 2003. Nucleic Acids Res. 2003, 31, 365-370.

(48) Cherezov, V.; Rosenbaum, D. M.; Hanson, M. A.; Rasmussen, S. G. F.; Thian, F. S.; Kobilka, T. S.; Choi, H.-J.; Kuhn, P.; Weis, W. I.; Kobilka, B. K.; Stevens, R. C. High-resolution crystal structure of an engineered human $\beta 2$-adrenergic G protein-coupled receptor. Science 2007, 318, 1258-1265.

(49) Rosenbaum, D. M.; Cherezov, V.; Hanson, M. A.; Rasmussen, S. G.; Thian, F. S.; Kobilka, T. S.; Choi, H. J.; Yao, X. J.; Weis, W. I.; Stevens, R. C.; Kobilka, B. K. GPCR engineering yields highresolution structural insights into beta2-adrenergic receptor function. Science 2007, 318, 1266-1273.

(50) Thompson, J. D.; Higgins, D. G.; Gibson, T. J. CLUSTAL W: Improving the sensitivity of progressive multiple sequence alignment through sequence weighting, position-specific gap penalties, and weight matrix choice. Nucleic Acids Res. 1994, 22, 4673-4680.

(51) Thompson, J. D.; Gibson, T. J.; Plewniak, F.; Jeanmougin, F.; Higgins, D. G. The CLUSTAL_X windows interface: flexible strategies for multiple sequence alignment aided by quality analysis tools. Nucleic Acids Res. 1997, 25, 4876-4882.

(52) Baldwin, J. M.; Schertler, G. F.; Unger, V. M. An alpha-carbon template for the transmembrane helices in the rhodopsin family of G-protein-coupled receptors. J. Mol. Biol. 1997, 272, 144-164.

(53) Sali, A.; Blundell, T. L. Comparative protein modelling by satisfaction of spatial restraints. J. Mol. Biol. 1993, 234, 779-815.

(54) Cornell, W. D.; Cieplak, P.; Bayly, I. R.; Gould, I. R.; Merz, K. M., Jr.; Ferguson, D. M.; Spellmeir, D. C.; Fox, T.; Caldwell, J. W.; Kollman, P. A. A second generation force field for the simulation of proteins, nucleic acids, and organic molecules. J. Am. Chem. Soc. 1995, 117, 5179-5197.

(55) Laskowski, R. A.; MacArthur, M. W.; Moss, D. S.; Thornton, J. M. PROCHECK: a program to check the stereochemical quality of protein structures. J. Appl. Crystallogr. 1993, 26, 283-291.

(56) Sylte, I.; Bronowska, A.; Dahl, S. G. Ligand induced conformational states of the 5-HT(1A) receptor. Eur. J. Pharmacol. 2001, 416, 3341.

(57) Shapiro, D. A.; Kristiansen, K.; Weiner, D. M.; Kroeze, W. K.; Roth, B. L. Evidence for a model of agonist-induced activation of 5-hydroxytryptamine $2 \mathrm{~A}$ serotonin receptors that involves the disruption of a strong ionic interaction between helices 3 and 6. J. Biol. Chem. 2002, 277, 11441-11449.

(58) Bissantz, C. Conformational changes of $\mathrm{G}$ protein-coupled receptors during their activation by agonist binding. J. Recept. Signal Transduction 2003, 23, 123-153.

(59) Ballesteros, J. A.; Jensen, A. D.; Liapakis, G.; Rasmussen, S. G. F.; Shi, L.; Gether, U.; Javitch, J. A. Activation of the beta 2-adrenergic receptor involves disruption of an ionic lock between the cytoplasmic ends of transmembrane segments 3 and 6. J. Biol. Chem. 2001, 276, 29171-29177.

(60) Shi, L.; Liapakis, G.; Xu, R.; Guarnieri, F.; Ballesteros, J. A.; Javitch, J. A. Beta2 adrenergic receptor activation. Modulation of the proline kink in transmembrane 6 by a rotamer toggle switch. J. Biol. Chem. 2002, 277, 40989-40996.

(61) Verdonk, M. L.; Cole, J. C.; Hartshorn, M. J.; Murray, C. W.; Taylor, R. D. Improved protein-ligand docking using GOLD. Proteins 2003, 52, 609-623.

(62) Mansour, A.; Meng, F.; Meador-Woodru, J. H.; Taylor, L. P.; Civelli, O.; Akil, H. Site-directed mutagenesis of the human dopamine D2 receptor. Eur. J. Pharmacol. 1992, 227, 205-214.

(63) Wang, C. D.; Gallaher, T. K.; Shih, J. C. Site-directed mutagenesis of the serotonin 5-hydroxytrypamine2 receptor: identification of amino acids necessary for ligand binding and receptor activation. Mol. Pharmacol. 1993, 43, 931-940.

\section{JM800602W}

